\title{
ATZERRITARREN ASKATASUNERAKO ESKUBIDEA ETA ASKATASUN-GABETZEA ATZERRITARTASUNARI BURUZKO ARAUDIAREN ARABERA ${ }^{1,2}$
}

\section{THE RIGHT TO LIBERTY OF FOREIGNERS AND THEIR DEPRIVATION OF LIBERTY IN APPLICATION OF THE REGULATIONS ON FOREIGNERS}

\author{
M. a Nieves Arrese Iriondo \\ Universidad del País Vasco / Euskal Herriko Unibertsitatea
}

Cómo citar / Nola aipatu: Arrese Iriondo, M. N. (2021). Atzerritarren askatasunerako eskubidea eta askatasun-gabetzea atzerritartasunari buruzko araudiaren arabera. Legebiltzarreko Aldizkaria - LEGAL - Revista del Parlamento Vasco, 2: 34-63 https://doi.org/10.47984/legal.2021.002

\section{LABURPENA}

Atzerritarren askatasun-gabetzea, bereziki, haien barneratzea, nazionalitatea dutenei aplikagarri ez zaizkien arrazoi zehatzen ondorio da. Lan honek, atzerritarren barneratzera eraman dezaketen kasuak azaldu ondoren, askatasunerako-eskubidearekin lotura duten prozedura-kontu garrantzitsuenak aztertzen ditu. Habeas corpus baliabideari ere egiten zaio aipu, nazionalitatea dutenek legez kontrakoak jotzen dituzten askatasun-gabetzeei aurre egiteko baliabide gisa. Edonola ere, atzerritarren egoera beste bat dela azpimarratu behar da, horien barneratzea, hala badagokio, epaileak erabaki behar baitu, modu horretan, erabakiak askatasun-gabetzearen kontrol judiziala berea eginez. Aurrera eramandako analisiaren xedea ez da aipatutako alderdiak sakontasunez jorratzea, baizik eta atzerritarren askatasunerako-eskubidearen zabaltzea azpimarratzea.

\section{GAKO-HITZAK}

Atzerritarrak, askatasunerako-eskubidea, barneratzea, esku-hartze judiziala.

1 Artikulu hau, Derechos humanos, potestad sancionadora y organización administrativa en la seguridad ciudadana izenburua duen eta Eusko Jaurlaritzak finantzatutako PIBA 2019-48 Ikerkuntza-proiektuaren baitan egindako lanaren fruitu da.

2 Artikulu hau gaztelaniaz ere eskuragarri dago https://doi.org/10.47984/legal.2021.002 


\section{ABSTRACT}

The deprivation of liberty of foreigners, in particular, their internment, responds to specific causes that are not taken into account in relation to those who have the nationality. This paper, after explaining the cases that may lead to the internment of foreigners, analyzes the most pressing procedural issues due to their connection with the right to liberty. It also refers to the figure of habeas corpus, a procedure available to those who have the nationality to deal with deprivation of liberty that they consider illegal. However, it is emphasized that the situation of foreigners is different, since their internment, when appropriate, will have to be taken by a judge, so the decision includes judicial control of the deprivation of liberty. The analysis does not pretend a detailed study of the mentioned aspects, but rather its main purpose is to insist on the extension of the right to liberty of foreigners.

\section{KEYWORDS}

Foreigners, right to liberty, internment, judicial intervention.

\section{RESUMEN}

La privación de libertad de las personas extranjeras, en particular, su internamiento, responde a causas específicas que no se contemplan con respecto de quienes tienen la nacionalidad. Este trabajo, tras exponer los supuestos que pueden desencadenar el internamiento de las personas extranjeras, analiza las cuestiones procedimentales más acuciantes por su vínculo con el derecho a la libertad. También se alude a la figura de habeas corpus, procedimiento del que disponen quienes tienen la nacionalidad para hacer frente a las privaciones de libertad que consideren ilegales. No obstante, se hace hincapié en que la situación respecto de las personas extranjeras es otra, ya que su internamiento, cuando procede, habrá de ser adoptado por un juez, por lo que la decisión incorpora el control judicial de la privación de libertad. El análisis llevado a cabo no pretende un estudio pormenorizado de los aspectos expuestos, sino que su propósito principal es incidir en la extensión del derecho a la libertad de las personas extranjeras.

\section{PALABRAS CLAVE}

Personas extranjeras, derecho a la libertad, internamiento, intervención judicial.

\section{AURKIBIDEA}

I. SARRERA.

II. ATZERRITARREN ASKATASUNERAKO ESKUBIDEA.

III. ATZERRITARREN ASKATASUN-GABETZEA ATZERRITARTASUNARI BURUZKO LEGEDIAN. 1. Bueltatzea, itzularaztea, kanporatzea. 2. Muga-postuan egindako askatasun-gabetzea. 3. Atzerritarren identifikazioaren ondorioz egindako askatasun-gabetzea: Herritarren Segurtasuna Babesteko Lege Organikoaren inguruko gogoetak.

IV. BARNERATZEAREN PROZEDURA-KONTUAK. 1. Barneratzea kautelazko neurri gisa. 2. Esku-hartze judiziala barneratzeko. 3. Barneratzearen iraupena. 4. Barneratze-autoaren aurkako errekurtsoa.

V. HABEAS CORPUS PROZEDURAREN BEREZITASUNAK ATZERRITARTASUNARI BURUZKO LEGEDIAREKIN BAT EGINDAKO ATXILOKETETAN. 1. Alderdi orokorrak. 2. Habeas corpus-a abiarazteko autoa. 3. Atzerritarren barneratzean esku-hartze judiziala eta habeas corpus-a ez onartzea.

VI. ONDORIOAK. BIBLIOGRAFIA. 


\section{SARRERA}

II. ATZERRITARREN

ASKATASUNERAKO ESKUBIDEA
Atzerritarren askatasunerako eskubideak dakarren lehenengo galdera bere hedadurari buruzkoa da, hots, ea nazionalitatea duten pertsonen eskubide berbera den edo haien kasuan onargarriak diren eskubide hura hautsiko luketen beste kasu batzuk. Hori dela eta, abiapuntua Konstituzioaren 13.1 artikulua da, zeinak atzerritarrei konstituzio-testuaren I. tituluan jasotzen diren askatasun publikoak bermatzen baitizkie "itunek eta legeak ezartzen dutenaren arabera". Askatasunerako eskubidearen irispidearen inguruko Konstituzio Auzitegiaren epaiak baztertu gabe, Giza Eskubideen Europako Auzitegiak aukera ugari izan ditu, oro har, Hitzarmenaren 5. artikuluan jasotzen den askatasunerako eskubidearen eremuari buruz erabakitzeko eta, bereziki, edonoren askatasun-gabetzea onargarria den kasuen harira, atzerritarren atxiloketa baimentzen duen kasu zehatzari buruz.

Lan honetan aztergai dagoena nagusiki honako hau da: batetik, atzerritarren askatasun-gabetzearen inguruko berezitasunak eta, bestetik, gabetze horren legezkotasunarekin zerikusia duten bermeak. Gai horiek ikuspuntu juridikotik duten garrantziaz gain, praktikan ere oso esanguratsuak dira, atzerritarren atxiloketak eta barneratzeak, batzuetan eskubideekiko begirunea zalantzan jartzen dutenak, ugariak dira-eta ${ }^{3}$.

Aurreratu denez, Konstituzioaren 13.1 artikuluak aipatzen du zeintzuk diren atzerritarrei dagozkien eskubide eta askatasunak "itunek eta legeak ezartzen dutenaren arabera”. Erreferentzia horrek esan nahi du, Konstituzioan bertan jasotzen diren salbuespenak izan ezik, atzerritarren oinarrizko eskubideen gozamena nazioarteko tratatu eta barne-legediaren edukiaren arabera ñabartu daitekeela ${ }^{4}$. Konstituzio Auzitegiak hasiera-hasieratik onartu zuen askatasun publikoek bere baitan hartzen dituztela oinarrizko eskubideak ere ${ }^{5}$. Horretaz gain, hiruko teoria ezaguna landu zuen, eta horren arabera, atzerritarren oinarrizko eskubideak honako era honetan sailkatuko dira:

I. giza duintasunari lotutako oinarrizko eskubideak, arrazoi horregatik pertsona guztiei era berean dagozkienak;

2. atzerritarrei ez dagozkien oinarrizko eskubideak, esaterako, Konstituzioaren 23. artikulukoak;

3 Ikus Euskal Autonomia Erkidegora mugatutako analisi bat, nagusiki enpirikoa, Barbero González, Blanco Fernández de Valderrama, Arrese Iriondo, González Murúa (2017); Barbero, Blanco eta Arrese (2018).

4 Konstituzio Auzitegiaren 99/1985 Epaia, irailaren 30ekoa, 2. OJ

5 Konstitizio Auzitegiaren 107/1984 Epaia, azaroaren 23koa. Konstituzio Auzitegiaren 115/1987 Epaiak, uztailaren 7 koak, gehiengoaren interpretazioarekin bat ez zetorren boto partikularra dauka. 
3. Konstituzioak nazionalitate espainiarra dutenei soilik aitortzen dizkien eskubideak, baina atzerritarrei ere luza dakizkiekeenak.

Konstituzioaren 17.1 artikuluaren arabera, "Pertsona guztiek dute askatasunerako eta segurtasunerako eskubidea. Inori ezin kendu zaio askatasuna, ez bada artikulu honek dioena betez eta legean ageri diren kasuetan eta moduan”. Askatasunerako eskubidea hiruko teoriaren lehenengo multzoan kokaturik dago, beraz, atzerritarrei ere dagokien eskubidea da. Hori horrela izan arren, Konstituzioak eskatzen du eskubidearen aitorpena legeek adierazitako betekizunen mende gelditzea. Giza Eskubideen Europako Hitzarmenaren 5.1 artikuluak ere pertsona orori aitortzen dio askatasunerako eta segurtasunerako eskubidea, eta inork ere ezin du bere askatasuna galdu artikuluak berak jasotako kasuetan izan ezik eta legeak zehazturiko prozedurarekin bat ${ }^{6}$.

Askatasunerako eskubidea gizarte demokratiko batean oinarrizko garrantzia duen eskubidea da ${ }^{7}$. Babesten denaren hedapena mugatzerakoan, lehenik eta behin, adierazi behar da eskubide horrek zentzu klasikoan gizabanakoaren askatasunari egiten diola aipu, hau da, askatasun fisikoari ${ }^{8}$, eta hori finkatzeko berdin da pertsona non dagoen, erabakigarriena baita pertsona etengabeko zaintzapean egotea eta lekua uzteko askatasunik ez izatea9.

Atzerritarren askatasun-gabetzea legezkoa izan daiteke nazionalitatea dutenen eremuan onartezinak izango liratekeen kasuetan. Azken horien atxiloketa euren askatasun pertsonalean gerta daitekeen eskusartzerik nagusiena da, eta horregatik azterketa zorrotz baten mende dago, gizartearen eskakizunen eta norberaren askatasunaren arteko haztapenak burutuko duena. Atzerritarrek, aldiz, Estatuko lurraldean haien sarrera edo egoitza baimentzen ez den bitartean, ez dute bertan egoteko eskubiderik. Atxilotuko diren ala ez erabakitzeko estatuek daukaten irizpidezkotasun-tartea handiagoa $\mathrm{da}^{10}$. Hala ere, agintariek euren jardunean izandako fede ona frogatu behar da, hala nola, atxiloketaren eta bilatzen den helburuaren arteko lotura estua, bai eta barneratzea leku aproposean egingo dela eta arrazoizkoa den iraupena izango duela ere ${ }^{11}$.

Europako Hitzarmenak zein Konstituzioak debekatzen dutena da askatasun-gabetzeak era arbitrarioan egitea. Agintariek modu arbitrarioan jardun duten zehazterakoan, Estrasburgoko Auzitegiak kontuan izan beharreko printzipio orokor batzuk finkatu ditu:

6 Giza Eskubideen Europako Auzitegiak artikulu horri buruz egindako interpretazioaz, ikus Arrese Iriondo (2015).

7 De Wilde, Ooms eta Versyp u. Belgika, 1971ko ekainaren 18ko Epaia, 65. atala; Winterwerp u. Herbehereak, 1979 ko urriaren 24 ko Epaia.

8 Charrier (2005: 59), Nowak (2005: 212).

9 Farhad Aliyeu u. Azerbaijan, 2010eko azaroaren 9ko Epaia, 163. atala; Salayeu b. Azerbaijan, 2010eko azaroaren 9ko Epaia, 42. atala.

10 Saadi u. Erresuma Batua, 2008ko urtarrilaren 29ko Epaia, 64. atala.

11 Kanagaratnam u. Belgika, 2011ko abenduaren 13ko Epaia; 94.-95. atalak; Suso Musa u. Malta, 2013ko uztailaren 23ko Epaia, 102. atala. 
I. agintarien ardura legedia aplikatzerakoan, fede txarra hautemanez gero askatasun-gabetzea ez baita legezkoa izango legedia zuzen aplikatu bada ere ${ }^{\mathrm{I}}$;

2. askatasun-gabetzea artikuluan bertan jasotzen diren murrizketekin bat etortzea;

3. askatasun-gabetzearen eremuaren eta atxiloketaren lekuaren eta baldintzen arteko egokitasuna;

4. askatasun-gabetzearen proportzionaltasuna ${ }^{13}$.

Asko dira atxiloketa arbitrarioa izan dela erabaki duten epaiak, gehienetan hura baimentzen duen erabakirik ez dagoelako ${ }^{14}$ edo, epailearen agindua egon arren, denborazko mugarik jartzen ez delako edo arrazoiak azaltzen ez direlako ${ }^{15}$. Era berean, atxiloketa arbitrarioa izango da adierazitako arrazoia ez den beste helburu baterako egin bada ${ }^{16}$. Gauzatutako askatasun-gabetzeak hasiera-hasieratik haren lekukotasuna egitea galdatzen du, bestela aitortu gabeko atxiloketa izango litzateke eta ${ }^{17}$. Atxiloketaren data, une eta lekuaren, atxilotutako pertsonaren izenaren zein atxiloketaren arrazoien, eta atxiloketa egin duenaren izenaren erregistrorik ez badago, atxiloketa ez da bateragarria izango Hitzarmenaren 5. artikuluak xedatutakoarekin ${ }^{18}$.

Askatasunerako eskubidearekin batera, Europako Hitzarmenaren 5. artikuluak eta Konstituzioaren 17.1 artikuluak segurtasunerako eskubidea ere bermatzen dute. Kontzeptu horrekin askatasunerako eskubidearen aurkako eraso arbitrarioak debekatzen dira soilik ${ }^{19}$. Auzitegiak azpimarratu du bereziki garrantzitsua dela segurtasun juridikorako printzipio orokorra asetzea askatasunerako eskubidea eraginda gertatzen denean, segurtasunerako eskubidea askatasun fisikoari legezko babesa ematen dion betebehar bat baino gehiago baita ${ }^{20}$. Ezinbestekoa da arauek askatasun-gabetzea ekar dezaketen inguruabarrak argitasun osoz definitzea, era horretan, edonork arrazoiz aurreikus dezan zeintzuk izango diren burututako ekintzaren ondorioak $^{21}$.

12 Farhad Aliyeu u. Azerbaijan, 2010eko azaroaren 9ko Epaia, 163. atala; Salayeu u. Azerbaijan, 2010 eko azaroaren 9ko Epaia, 42. atala.

13 James, Wells eta Lee v. Erresuma Batua, 2012ko irailaren 18ko Epaia, 192.-195. atalak.

14 Kharchenko u. Ukrania, 2011ko otsailaren 10eko Epaia, 69. atala.

15 Sabirou u. Errusia, 2010eko otsailaren 11ko Epaia, 30. atala; Feldman u. Ukrania, 2010eko apirilaren 8ko Epaia, 72. eta 73. atalak; Farhad Aliyeu u. Azerbaijan, 2010 eko azaroaren 9 ko Epaia, 166. atala.

16 Gafgaz Mammadou u. Azerbaijan, 2015eko urriaren 15eko Epaia, 103.-110. atalak.

17 Navalnyy y Yashin u. Errusia, 2014ko abenduaren 4ko Epaia, 94. eta 95. atalak.

18 Kurt u. Turquía, 1998ko maiatzaren 25eko Epaia, 125. atala.

19 De Meyer (1999: 190).

20 Giorgi Nikolaishuili u. Georgia, 2009ko urtarrilaren 13ko Epaia, 53. atala.

21 Baranoswki u. Polonia, 2000ko martxoaren 28ko Epaia, 52. atala; Ciobanu u. Errumania, 2013ko uztailaren 9ko Epaia, 64. atala. 
Atzerritarren askatasun-gabetzearen eremuan, haiek ez dute izango delitu bat egiteagatik behin-behineko espetxealdian dauden pertsonek duten babes-maila bera ${ }^{22}$, lehenengo kasuan arau-hauste administratibo bat egin duten pertsonak baitira; beraz, haien portaera ez da delitua ${ }^{23}$. Hori horrela izanda ere, oro har, Konstituzioaren 17. artikuluan aitortzen diren eskubideen gozamena ere dagokie ${ }^{24}$. Gainera, era horretako atxiloketak arbitrarioak izango dira ez badago atxiloketaren dataren, denboraren eta barneratutako pertsonen kokagunearen, deportazioa burutu aurretik askatasunik gabe egon diren denboraren, deportazioaren dataren eta lekuaren erregistrorik, askatasun-gabetzearen amaierari buruzko informaziorik ez litzateke egongo-eta ${ }^{25}$. Bestalde, askatasun gabeturik dagoen pertsonak nazioarteko babesa eskatzen badu, kanporatze-neurria eten egingo da, baina horrek ez dauka zertan izan eraginik atxiloketarengan; galdatzen dena asiloari buruzko prozedura ahalik eta lasterren amaitzea da. Hala ere, askatasun-gabetzea justifikatuko duten arrazoi sakonak egotea ezinbestekoa $\mathrm{da}^{26}$.

III. ATZERRITARREN ASKATASUN-GABETZEA ATZERRITARTASUNARI BURUZKO LEGEDIAN

\section{BUELTATZEA, ITZULARAZTEA, KANPORATZEA}

Atzerritartasunari buruzko Lege Organikoak atzerritarrak atxilotu ahal izateko zenbait kasu jasotzen du. Era horretan, Giza Eskubideen Europako Hitzarmenaren agindua betetzen da, aukera hori legeren batean aurreikusirik egotea eskatzen baitu ${ }^{27}$. Horrela egingo ez balitz, atxiloketaren arbitrariotasuna gertatzeaz gain, legez kontra atxilotu diren pertsonei habeas corpus moduko oinarrizko babesez baliatzeko aukera kenduko litzaieke ${ }^{28}$, aurrerago ikusiko denez.

Atzerritarra barneratu ahal izango da astun edo oso astun gisa tipifikaturiko zenbait arau-hauste ustez egin izanagatik bere aurkako espediente zehatzailea irekitzen denean. Kasu horietan guztietan barneratzea justifikatzen duena da jar daitekeen

22 Chahal u. Erresuma Batua, 1996ko azaroaren 15eko Epaia, 112. atala; Kolesnik u. Errusia, 2010ko ekainaren 17ko Epaia, 80. atala; Efremidze u. Grezia, 2011ko ekainaren 21eko Epaia, 52. atala; M. eta beste batzuk u. Bulgaria, 2011ko uztailaren 26ko Epaia, 61. atala.

23 Kolesnik u. Errusia, 2010eko ekainaren 17ko Epaia, 80. atala; Efremidze u. Grezia, 2011ko ekainaren 21eko Epaia, 52. atala; M. eta beste batzuk b. Bulgaria, 2011ko uztailaren 26ko Epaia, 61. atala.

24 Donaire Villa (2012: 509).

25 Ranjbar eta beste batzuk u. Turkia, 2010eko apirilaren 13ko Epaia, 42. eta 43. atalak.

26 A. A. u. Grezia, 2010 eko uztailaren 22ko Epaia, 90.-94. atalak; M. A. u. Zipre, 2013ko uztailaren 23ko Epaia, 209. atala; E.K. u. Grezia, 2021eko urtarrilaren 14ko Epaia, 93.-99. atalak.

27 Amuur u. Frantzia, 1996ko ekainaren 25eko Epaia. 
zehapena Estatuko lurraldetik kanporatzea izatea ${ }^{29}$. Edonola ere, legegileak, jarraitu beharreko prozedurari dagokionez, lehenespeneko prozedura eta prozedura arrunta bereizten ditu $^{30}$. Eta bereizketa ez da hutsala, bigarren kasuan ez baita posible izango atzerritarra barneratzea prozeduraren izapidetzeak irauten duen bitartean, ezta borondatezko irteerarako epean ere ${ }^{31}$. Era berean, legeak dolozko jokabidearengatik urtebetetik gorako zigor askatasun-gabetzailearekin zigortutako atzerritarra kanporatzea ere aurreikusten du, eta kasu horretan, helburu berarekin, pertsona hori barneratu ahal $\mathrm{da}^{32}$.

Bestalde, legeak prozedura zehatzaileren baten baitan ez dauden atzerritarrak barneratzeko aukera ere jasotzen du. Estatuko lurraldean sartzea ukatzen denean eta itzularaztea erabakitzen denean gerta daiteke hori. Sarrera ukatuko da atzerritarra horretarako ezarritako tokietatik nahitaezkoa den dokumentaziorik gabe sartzen saiatzen denean. Horren ondorioa jatorrizko puntura bueltatzea da. Baina, bueltatze hori poliziaren kontrolpean dagoenetik hirurogeita hamabi ordu baino gehiagoz atzera daitekenez, instrukzio-epaileak, sarrera ukatu duen agintariak eskaturik, atzerritarraren barneratzea erabaki dezake ${ }^{33}$.

Hori ezartzen duen artikuluaren hitzez-hitzezkoak dio "Atzerritarrak bueltatzea erabakitzen duen gobernu-agintariak instrukzioko epailearengana joko du, bueltatzea hirurogeita hamabi ordu baino gehiago atzeratzen bada, instrukzioko epaile horrek erabaki dezan atzerritarrak zein lekutan barneratu behar diren, bueltatzeko unea heldu arte". Nafarroako Parlamentuak artikulu horren aurka (beste batzuen artean) konstituzio-kontrakotasuneko errekurtsoa jarri zuen, Konstituzioaren 17.1 eta 17.2 artikuluak bortxatzeagatik, ulertu zuelako ez zela bermatzen hirurogeita hamabi ordu horietatik kanpo askatasun-gabetzeari buruzko erabakia epaileak hartuko zuela, epailea barneratzearen lekua zehaztera mugatu beharko litzateke-eta. Baina Konstituzio Auzitegiaren interpretazioari jarraituz, bueltatzea hirurogeita hamabi ordu baino gehiagoz atzeratzen denean, epaileari eskatu beharko zaio atzerritarraren askatasun-gabetzea mantentzea. Beraz, epaileak askatasun osoz hartuko luke dagokion erabakia ${ }^{34}$.

Kasu horretan, atzerritarrak barneratzeko lekuek espetxe-izaerarik izango ez dutela ñabartzen da, eta leku horiek gizarte-zerbitzuak, zerbitzu juridikoak eta kultura- eta osasun-zerbitzuak izango dituztela, barneratutakoek eskubide anbulatorioaz bakarrik

29 Atzerritarren Lege Organikoaren 62. art.

30 Atzerritarren Lege Organikoaren 63. eta 63. bis art.

31 Atzerritarren Lege Organikoaren 63. bis 3 eta 64.1 art.

32 Atzerritarren Lege Organikoaren 57. art.

33 Atzerritarren Lege Organikoaren 60. art.

34 Konstituzio Auzitegiaren 237/2007 Epaia, azaroaren 7koa, 15. OJ 
gabetuko direlarik ${ }^{35}$. Bueltatze-kasuetan egon daitekeen barneratzeari buruzko ñabardura horrek, hala nola, "lekua" hitza erabiltzeak "zentroa" erabili ordez, barneratzea kasu horietan beste toki batzuetan egin daitekeelako izan daiteke, eskuarki muga-postuan bertan edo aireportuetako errefusatuen nazioarteko gunean ${ }^{36}$.

Bestetik, itzularaztea erreakzio-neurri bat da kanporatuak izan arren, Estatuko lurraldean sartzeko debekuari jaramonik egin gabe edo legearen aurka lurraldean sartu nahi dutenen aurka. Aurreko kasuaren antzera, itzularaztea hirurogeita hamabi ordu baino gehiagoz atzeratzen bada, instrukzio-epaileak itzuleraren objektu izango diren atzerritarren barneratzea baimendu behar $\mathrm{du}^{37}$.

Azkenik, kanporatze-zehapena ezarri denean ere atzerritarra barneratu ahal izango da ez duenean lurraldea utzi nahi ${ }^{38}$. Kasu horretan, egiatan, pertsonak derrigortzearen figura emango litzateke nahitaez betearazteko teknika gisa ${ }^{39}$. Hurrengo epigrafean figura horren eta bueltatzearen arteko ezberdintasunak ikusiko dira.

\section{MUGA-POSTUAN EGINDAKO ASKATASUN-GABETZEA}

Legearekin bat lurraldean muga-postuetatik sartu nahi dutenen atxiloketaren inguruan sortzen den galdera nagusia da askatasun-gabetzea den ala ez muga-postu horietako geletan poliziaren kontrolpean egotea bueltatzea gauzatu arte. Konstituzio-jurisprudentziaren arabera, ez dago kasu guztientzat baliagarria den erantzun bakarra, erantzuna egoera bakoitzaren inguruabarren araberakoa izango da-eta.

Zehazki, bi pertsonari sarrera ukatzearen harira, Konstituzio Auzitegiak baieztatu zuen horien egoera ez zela atxiloketa, baizik eta lurraldean sartzeko eragozpena. Horren arabera, pertsonaren askatasunerako eskubideak -pertsona orori dagokiona nazionalitatea zein den aintzat hartu gabe- ez darama berarekin lurraldean sartzeko eskubidea, hori Konstituzioaren esanetan nazionalitatea dutenei soilik dagokie, bai eta legearekin bat jarduten duten atzerritarrei ere. Hori guztia kontuan izanda aireportuko nazioarteko gunea Estatuko lurraldea da eta muga-zerbitzuan dauden funtzionarioek Estatuaren subiranotasun oso eta esklusiboari atxikitako ahal publikoak egikaritzen dituzte. Erabakigarria da askatasun anbulatorioa mugatua izanda muga-postuan egotea jatorrizko lekura bueltatzeko hegazkinaren eskuragarritasunaren mende dagoela ${ }^{40}$.

35 Atzerritarren Lege Organikoaren 60.2 art.

36 Alonso Pérez (2002), Teixeira Rodríguez (2005: 732), Fernández Arévalo (2006: 42).

37 Atzerritarren Lege Organikoaren 58. art. Figura horri buruz, ikus Moya Malapeira (2002: 189-262).

38 Atzerritarren Lege Organikoaren 64. art.

39 Requejo Rodríguez (2006: 67-70).

40 Konstituzio Auzitegiaren 55/1996 Autoa, martxoaren 6koa, 3. eta 5. OJ. 
Hala ere, azaldutakoak ez du esan nahi aireportuko errefusatutakoentzat gunean egotea sekula ez denik askatasun-gabetzea. Batzuetan, Konstituzioaren 17.2 artikulura bidera daitekeen prebentziozko atxiloketa egoera gerta daiteke. Horrela gertatzen da, adibidez, itzularazte- edo kanporatze-agindua duen lurralde barruan atzemandako atzerritarra leku horretara eramaten denean. Kasu horretan, aurretiazko administrazio-ebazpen baten nahitaezko betearazpena izango litzateke, eta horrek, irteerara arte, atzerritarra fisikoki leku horretara zuzentzea eskatzen du. Nahiz eta ez den eskatzen nahitaezko betearaztea hirurogeita hamabi orduak baino lehenago burutzea, bada beharrezkoa atzerapenik gabe egitea. Horregatik, jatorrian prebentziozko atxiloketa zena (itzularazte-agindua eman eta jakinarazten denean gertatzen dena), itzularaztearen administrazio-ebazpenaren nahitaezko betearaztearekin amaitzen da. Hala ere, horrek ez du esan nahi muga-postuetan egindako askatasun-gabetzeak denbora-mugarik ez duenik; galdatzen dena da administrazio-egintza betearazteko ezinbesteko denbora baino gehiagoz ez luzatzea, eta denbora hori ezin izango da izan egintza betearazteak baldintza normaletan behar duena baino askoz ere luzeagoa ${ }^{41}$.

Esandakoaren ondorioz, kanporatze- edo itzularazte-agindurik egongo ez balitz, prebentziozko atxiloketa egoerak jarraituko luke, eta hori bai egongo litzateke hirurogeita hamabi orduko mugaren mende. Horren harira, beste Estatu batzuetara irteteko askatasuna egoteak ez du prebentziozko atxiloketa-egoera indargabetzen, atzerritarrak bere mugimendu-askatasuna toki mugatu eta itxi batera mugaturik baitu, hori legitimatzen duen titulurik gabe. Horregatik aireportu bateko errefusatuentzako gunean kokaturik dauden atzerritarrek habeas corpus-a eskatzeko eskubidea dute, eta horren arabera, epaile batek egiaztatu beharko luke itzularazte- edo kanporatze-agindua dagoen, eta ez egotekotan, legezkoa edo legez kontrakoa izan daitekeen prebentziozko atxiloketa gertatu den ${ }^{42}$.

Muga-postuetan nazioarteko babes-eskaerak aurkezteak ohikoa dena baino azkarragoa den prozedura irekitzen du. Lehenik eta behin, eskaera ez onartzea gerta daiteke, lau eguneko epean erabaki behar dena. Legeak aurreikusten dituen kasuetan eskaera ezezta daiteke, eta hori ere lau eguneko epean erabakiko da. Eskaera onartzen ez bada, bai eta eskaerari ezezkoa ematen bazaio ere, bi eguneko epean erabaki beharreko berrazterketa eska daiteke ${ }^{43}$. Orain aztergai dugunari begira, erabakiak hartzen ez diren bitartean, eskatzaileak horretarako gaitutako lekuetan egongo direla dio legeak ${ }^{44}$.

Horren inguruko zalantza da muga-postuetan egote hori poliziaren kontrolpeko askatasun-gabetzea den ala ez. Konstituzio Auzitegiak zalantza hori argitu

\footnotetext{
41 Konstituzio Auzitegiaren 179/2000 Epaia, ekainaren 26koa, 2. OJ.

$42 \mathrm{KAE}$ 174/1999, irailaren $27 \mathrm{koa}, 3 ., 4$. eta 5. OOJJ.

43 Asiloari buruzko Legearen 21. art

44 Asiloari buruzko Legearen 22. art.
} 
zuen $^{45}$. Abiapuntua honako hau da: nazioarteko babesa eskatzen duenari, lurraldean sartzeko beharrezko betekizunak betetzen ez baditu, behin-behineko sarrera mugatua utziko zaio, muga-postuan horretarako gaituriko leku egokietan egon baitaiteke, baina egoera hori ez da sartzeko edo zirkulatzeko konstituzio-eskubidearen baliokidea ${ }^{46}$. Muga-postuan egotea, prebentziozko atxiloketa ez izateagatik, ez dago hirurogeita hamabi ordutara mugaturik, nahiz eta denboran mugaturik egon behar den. Bertan egoteko gehienezko denbora kasu bakoitzean jarraitzen den helburuaren mende dago. Asiloari buruzko legediak modu adierazian ezartzen du, batetik, eskaera ez onartzeko edo ezezteko epea lau egunekoa dela eta, bestetik, berraztertzeko eskaera erabakitzekoa bi egunekoa, beraz, askatasun-gabetzearen denbora-muga argi eta garbi zehazturik dago. Muga-postuan egotea Konstituzioarekin bat datorrela justifikatzen da, gainera, nazioarteko babesari buruzko eskaera aurkeztu eta hurrengo lau egunetan eskatzailearen egoera erabakitakoaren arabera alda daitekeelako. Eskaera onartzen bada, lurraldean sartzeko eta egoteko behin-behineko baimena izango du; ez bada epe barruan erabakitzen, isiltasun positiboa sortuko da, eta horretan ere sartzeko eta egoteko behin-behineko baimena izango du; eskaera onartzen ez bada edo ezezten bada, ondorioa eskatzailearen kanporatzea izango da, nahiz eta berraztertzeko eskaerak neurriaren betearaztea etengo duen, eskatutakoa ebazten ez den bitartean. Azken kasu horretan, muga-postuan egotearen luzapenaren arrazoia eskatzaileak berak aurkeztutako eskaera da. Gainera, bien bitartean eskatzailea kanporatzea ezinezko izango da. Ondorioz, murrizketak ziurtasun- eta aurreikuspen-eskakizunei erantzuten dio. Era berean, ezarritako epeak proportziozkotzat jotzen dira, estuki beharrezkoa denari mugatzen baitira, kontuan izan behar baita eskaera ebatzi behar dela ${ }^{47}$.

Muga-postuetan aurkeztu diren nazioarteko babesari buruzko eta horiek berraztertzeko eskaerei erantzuteko lau eta bi eguneko epeen inguruan adierazi behar da horien zenbaketak erregimen berezia duela, ez baita jarraitzen Administrazio Publikoen Administrazio Prozedura Erkideari buruzko Legeak ezarritakoa. Azken horrek zehazten du, besterik gabe, egunetan adierazitako epeetan ez direla zenbatuko larunbat, igande eta jaiegunak ${ }^{48}$. Atzerritarrak bere mugimendu-askatasuna mugaturik daukan prozedura bat dela kontuan izanda, Auzitegi Gorenak ulertu du egunetan adierazitako epeak zenbatzeko ohiko modua era horretako egoerek galdatzen duten azkartasun- eta premia-printzipioen aurkakoa izango litzatekeela. Hori dela eta, epea ez da egun jakin

\footnotetext{
45 KAE 53/2002, otsailaren 27koa. Gaur egun indargabeturik dagoen 5/1984 Legearen, martxoaren 26koa, asiloari buruzkoaren 5.7 artikuluaren 3. atalak, antzeko aurreikuspena zuen, 9/1994 Legeak, maiatzaren 19koak, sartutakoa. Herri-defendatzaileak xedapenaren aurka konstituziokontrakotasunezko errekurtsoa jarri zuen.

46 KAE 53/2002, otsailaren 27koa, 4. OJ.

47 Konstituzio Auzitegiaren 53/2002 Epaia, otsailaren 27koa, 6., 7. eta 8. OJ.

48 Urriaren 1eko 39/2015 Legearen 30.2 art.
} 
batetik zenbatuko, baizik eta une zehatz batetik ${ }^{49}$, hau da, ordutik ordura eta larunbat, igande eta jaiegunak ere zenbatuz ${ }^{50}$.

Epeak zenbatzeko modu hori barneratze-zentroetan aurkeztutako nazioarteko babes eskaerei ere luzatzen zaie. Muga-postuetan edo barneratze-zentroetan eskaerak aurkezten dituztenen egoerak ezberdinak dira. Lehenengo kasuan, lurraldean sartu ezin diren pertsonak izanik, mugan, poliziaren kontrolpean dauden pertsonak dira, hori baimentzen duen ebazpen judizialik gabe. Bigarrenean, aldiz, eskatzaileak dagoeneko lurraldean daude eta horien barneratzea epaile batek erabaki du. Azken kasu horretan, nazioarteko babes-eskaera aurkeztearen ondorioz, bueltatzea, itzularaztea edo kanporatzea eten egingo da eskaerari buruzko erabakia hartzen ez den bitartean ${ }^{51}$. Nahiz eta eskaeraren erantzunak ez izan premia bera kasu batean eta bestean, egoerak ezberdinak izateak ez dauka ezberdintasunik epeen zenbaketan.

Giza Eskubideen Europako Auzitegiak ere adierazi du aireportu bateko nazioarteko gunean egoteak ez duela esan nahi atzerritarra askatasun-gabeturik dagoela, egote hori larregi luzatzen den kasuan izan ezik ${ }^{52}$. Baina, nahiz eta askatasun-gabetzerik ez egon, pertsona horrek legezko eta gizarte-laguntzarako eskubidea dauka, bai eta egotearen luzapena auzitegi batek erabakitzekoa ere. Azken horrek aireportuko igarotze-gunean burututako egotea legez kontrakoa dela erabakitzen badu, egotea egitatezko bidea sortuko duen askatasun-gabetzea izango litzateke ${ }^{53}$. Horren harira, ez da nahikoa izango atxilotutako pertsonek gunea "kanporantz" utzi dezaketela baieztatzea $^{54}$. Aireportuko igarotze-gunean egon bitartean muga gurutzatu ez arren, pertsona hori Estatuaren jurisdikziopean dago, eta nahiz eta atxiloketarik ez egon, askatasunaren gabetzea edo murriztea dago. Egoera hori begi bistakoa da gela utzi ezin dezakeen subjektu baten kasuan. Atea kanpotik itxita zegoen eta komunera eta tabernara joaten zen bakoitzean, muga-kontroleko poliziaren zaintza etengabekoa zen ${ }^{55}$.

\section{ATZERRITARREN IDENTIFIKAZIOAREN ONDORIOZ EGINDAKO ASKATASUN- GABETZEA: HERRITARREN SEGURTASUNA BABESTEKO LEGE ORGANIKOAREN INGURUKO GOGOETAK}

Aurreko lerroetan atzerritarrak barneratu ahal izateko kasurik ohikoenak azaldu badira ere, poliziak egindako identifikazio-kontrolen ondorioz gerta daitezkeen aska-

49 AGE, 2019ko abenduaren $17 \mathrm{koa}$.

50 AGE, 2016ko uztailaren 20koa.

51 AGE, 2019ko irailaren 23koa.

52 Z. A. eta beste batzuk U. Errusia, 2019ko azaroaren 21eko Epaia, 164-171. atalak.

53 Riad e Idiab u. Belgika, 2008ko urtarrilaren 24ko Epaia, 75. atala.

54 Amuur u. Frantzia, 1996ko ekainaren 25eko Epaia, 43-48. atalak; Riad eta Idiab u. Belgika, 2008ko urtarrilaren 24ko Epaia, 68. atala.

55 Nolan eta K. u. Errusia, 2009ko otsailaren 12ko Epaia, 95., 96. eta 99. atalak. 
tasun-gabetzeak ere aipatu nahi dira. Horretarako, aintzat hartu beharreko araudia, atzerritartasunari buruzkoaz gain, herritarren segurtasunaren babesari buruzkoa $\mathrm{da}^{56}$. Zehazki, legeak jasotzen du atzerritarrek jatorrizko herrialdeko agintari eskudunek jaulkitako nortasun-egiaztagiriak eduki eta soinean eramateko eskubidea eta betebeharra dutela, bai eta egoera erregularrean daudela egiaztatzen duten agiriak ere ${ }^{57}$. Dokumentazio hori erakutsi beharra (pasaporteaz ari da) derrigorrezkoa da "agintaritzak edo horren agenteek horrela egiteko eskatuz gero" ${ }^{58}$. Gaiarekin hasi aurretik atzerritarrek euren nortasuna eta administrazio-egoera egiaztatzeko agiri ezberdinak izan ditzaketela azpimarratu nahi $\mathrm{da}^{59}$. Adibidez, eta bide guztiak agortzeko asmorik gabe, pasaporte edo bidai-agiri eta bisaz gain, atzerritarren nortasun-txartela ${ }^{60}$ edo dokumentaziorik ez duten atzerritarren behin-behineko dokumentua ${ }^{61}$ aipa daitezke.

Gakoa, eremu honetan, bi alderdi nagusitan ardazten da: batetik, noiz dauden gaiturik segurtasun-indar eta -kidegoak pertsona bati bere identifikazioa eskatzeko eta, bestetik, ea identifikazioa ez erakusteak, hori eskatu denean, askatasun-gabetzera eraman dezakeen. Lehenik eta behin adierazi behar da identifikazioa eta administrazio-egoera egiaztatzeko eskatzea askatasunerako eskubidean eskua sartzea dela ${ }^{62}$, eta hori lege mailako arau batean aurreikusirik egon behar dela ${ }^{63}$. Lege horrek, gainera, aintzat hartu behar ditu behar-, egokitasun- eta proportzionaltasun-printzipioak ${ }^{64}$. Herritarren Segurtasuna Babesteko Lege Organikoak zeregin hori burutu du, eta identifikazioa honako kasu hauetan egin daitekeela dio: "a) Arau-hauste bat egiten parte hartu ahal izan duten zantzuak daudenean. b) Baldin eta, gertatutako inguruabarren arabera, nortasuna egiaztatzea zentzuz beharrezkoa dela jotzen badute delitu bat egin dadin prebenitzeko" ${ }^{65}$.

Haatik, ez lege horrek ez eta atzerritartasunari buruzkoak ere, ez dute aipatzen noiz eska daitekeen administrazio-egoera egiaztatzen duen dokumentazioa, nahiz eta atzerritarrek egoera hori egiaztatzen duen dokumentazioa soinean eramateko duten betebeharretik Konstituzio Auzitegiak ondorioztatu duen polizia-agenteek eska deza-

56 4/2015 Lege Organikoa, martxoaren 30ekoa, Herritarren Segurtasuna Babestekoa.

57 Herritarren Segurtasuna Babesteko Lege Organikoaren 13.1 art.

58 Herritarren Segurtasuna Babesteko Lege Organikoaren 11.4 art.

59 Gai horri buruzko analisi zehatza Bolaño Piñeiro (prentsan).

60 Atzerritarren Erregelamenduaren 210.1 art.

61 Atzerritarren Erregelamenduaren 211.6 art.

62 Velasco Caballero (2007: 235).

63 Agirreazkuenaga Zigorraga (1994: 14). Egileak dio Herritarren Segurtasuna Babesteko 1/1992 Lege Organikoa onartzeko xede nagusietako bat "poliziaren esku-hartze estandarrak" deiturikoei legezko estaldura hori ematea izan zela.

64 Guillén Pérez eta Prieto González (2017: 325-352).

65 Herritarren segurtasuna babesteko Lege Organikoaren 16.1 art. 
ketela, eta atzerritarrak halakorik ez badu eta administrazio-egoera irregularrean egotearen susmoak badaude, atzerritartasunari buruzko legedia aplikatuz, pertsona hori atxilotzea zilegi dela. Portaera horrek ez luke bortxatuko Konstituzioaren 17. artikuluko askatasunerako eskubidea ${ }^{66}$. Interpretazio hori kritikagarria da. Polizia Nazionalaren Kidegoak Estatuko lurraldean sartzea eta lurraldetik irtetea kontrolatzeko funtzioak ditu, bai eta atzerritartasunari, babes eta asiloari, estradizioari, kanporatzeari, emigrazio eta immigrazioari buruzko legedietan jasotakoak ere ${ }^{67}$. Hala ere, aipatutako legediak ez du aurreikusten muga-postuetatik kanpo aurrera eraman daitezkeen administrazio-egoerari buruzko kontrolik. Edo beste hitz batzuekin esateagatik, atzerritarrei dokumentazio hori eskatzea zilegi izango da segurtasunaren eremuan soilik, baina ez atzerritartasunari buruzko legedia ez betetzeagatik.

Beste kontu bat da administrazio-egoera irregularraz ohartzea Herritarren Segurtasuna Babesateari buruzko Legearen 16. artikulua aplikatuz egindako identifikazio-kontrolaren ondorio izatea. Horrek dakarren galdera da ea poliziaren kontrolak artikulu hori aplikatzeko egiten diren edo beste faktore batzuei erantzuten dieten, adibidez, identifikatu nahi diren pertsonen profil etnikoari. Horrek lan honetan jorratuko ez diren beste arazo batzuk planteatzen ditu ${ }^{68}$.

Herritarren Segurtasuna Babesteari buruzko Lege Organikoak azpimarratzen du baita ere identifikazio-eginbideek, besteak beste, ez dituztela atxiloketak bete behar dituen formalitate berberak bete beharko ${ }^{69}$. Edonola ere, identifikazioa ezinezkoa denean edo pertsonak bere burua identifikatzeari uko egiten dionean, "agenteek, delitu bat egin dadin eragotzi edo arau-hauste bat zehatu ahal izateko, identifikatu ezin den pertsonari eginbide hori egiteko baliabide egokiak dituzten polizia-instalazio hurbilenetara joateko eskatu ahal izango diote, identifikatzeko soilik eta ezinbesteko denborarako (inola ere sei ordu baino gehiagorako)" ${ }^{\prime \prime 0}$. Aurreko herritarren segurtasunaren babesari buruzko legearekin ez bezala ${ }^{71}$, egun indarrean dagoenak polizia-instalazioetan pertsona egon daitekeen gehienezko denbora zehazten du. Edozein kasutan, Konstituzio Auzitegiak adierazi zuen gehienezko epea ez jasotzeak ez zekarrela Konstituzioaren 17. artikulua bortxatzea, beti ere egote hori behar-beharrezko denborakoa bada ${ }^{72}$.

Kontuan izanda atzerritarrak identifikatzen direla administrazio-egoera irregularrean daudela susmatzen delako eta horren ondorioa haien atxiloketa izan daitekeela,

66 Konstituzio Auzitegiaren 86/1996 Epaia, maiatzaren 21ekoa, 2. eta 5. OJ.

67 Segurtasuneko Indar eta Kidegoen Lege Organikoaren 12.1.A), b) eta c) art. (2/1986 Lege Organikoa, martxoaren 13koa).

68 Gai horri buruz, ikus, García Añón, Bradford, García Sáez, Gascón Cuenca, Llorente Ferreres (2013), Lasagabaster Herrarte (prentsan).

69 Herritarren Segurtasuna Babesteko Lege Organikoaren 19.1 art.

70 Herritarren Segurtasuna Babesteko Lege Organikoaren 16.2 art.

71 1/1992 Lege Organikoaren 20.2 art.

72 Konstituzio Auzitegiaren 341/1993 Epaia, azaroaren 18koa, 6.A OJ. 
une horretatik aurrera Konstituzioaren 17. artikuluko bermeez gozatuko dute, zehazki, polizia-atxiloketa gehienez hirurogeita hamabi ordukoa izatea. Baina gehienezko epe horrek ez du "legezko" bihurtzen tarte horretan mantentzen den edozein askatasun-gabetze, egoera hori dagozkion egiaztapenak burutzeko behar-beharrezko denboraz soilik baitago justifikaturik. Beraz, egiaztapenok denbora gutxiago behar izan badute, atxiloketa mantentzea Konstituzioaren 17. artikuluaren kontrakoa izango litzateke ${ }^{73}$. Kontuan izan behar da identifikatzeari edo identifikatzeko egiaztapen edo jardueretan laguntzeari uko egitearen kasuan legeak berak Zigor Kodera, Prozedura Kriminalaren Legera eta Legean bertan xedatutakora bidaltzen duela ${ }^{74}$. Horretaz gain, Atzerritarrei buruzko Legeak ere arau-hausteen zerrenda dauka, eta horien artean, isunarekin edo lurraldetik kanporatzearekin zeha daitekeen arau-hauste astun gisa jasotzen da egoera irregularrean egotea. Beraz, badirudi onargarria dela, identifikazio-kontrol batean jakiten bada atzerritarra egoera irregularrean dagoela, hura polizia-instalazioetara eramatea espediente zehatzailea irekitzeko ${ }^{75}$.

\section{BARNERATZEAREN PROZEDURA-KONTUAK}

Atzerritarren barneratzeak xehetasunez aztertuak izatea merezi duten alderdi ugari dauka. Edonola ere, lan honen xedea ez da figura horren azterketa zehatz eta sakona egitea ${ }^{76}$, baizik eta barneratutako pertsonen askatasunerako eskubidearengan eragin zuzena duten alde zehatzei buruz hausnartzea.

\section{BARNERATZEA KAUTELAZKO NEURRI GISA}

Barneratzea honako era honetan defini daiteke: "izaera pertsonala duen kautelazko neurri judiziala, zeinaren bidez kanporatze, bueltatze edo itzularazte administrazio-prozedura batek eragiten duen atzerritarraren askatasuna gabetzen baita"77.

Behin kanporatze-zehapena proposatu dezakeen prozedura zehatzailea hasi denean, instrukzio-egileak zenbait kautelazko neurri erabaki dezake, besteak beste, agintari eskudunen aurrean aldian-aldian aurkeztea, nahitaez toki jakin batean bizitzea ${ }^{78}$, pasaportea edo naziotasuna egiaztatzeko agiria kentzea, gehienez hirurogeita hamabi

\footnotetext{
73 Konstituzio Auzitegiaren 341/1993 Epaia, azaroaren 18koa, 6.A OJ; Konstituzio Auzitegiaren 86/1996 Epaia, maiatzaren 21ekoa, 8. OJ.

74 Herritarren Segurtasuna Babesteko Lege Organikoaren 16.5 art.

75 Velasco Caballero (2007: 234).

76 Horri buruz argitaratu diren lanak ugariak dira, bibliografian jaso direnak besteak beste.

77 Tomé García (2014: 25).

78 Neurri hori Konstituzioarekin bat zetorrela erabaki zen, Konstituzio Auzitegiaren 260/2007 Epaia, abenduaren 20koa, 5. OJ
} 
ordu iraungo duen kautelazko atxiloketa, barneratzea aurretiazko baimen judizialarekin. Zalantzarik gabe, barneratzea da har daitezkeen kautelazko neurrien artetik murriztaileena.

Kautelazko neurri gisa, neurri horrek helburu bat jarraitu behar du, eta helburu hori, atzerritartasunari buruzko legeak dioen bezala, kanporatze-agindua betearaziko dela bermatzea da, azkenean hori bada prozedura zehatzailean erabakitako zehapena. Horretarako, eta edozein kautelazko neurri erabakitzen denean gertatzen denez, epailearen erabakia neurri horiek berezkoak dituzten aurrekarietan oinarritu behar $\mathrm{da}$, hots, fumus boni iuris eta periculum in mora ${ }^{79}$. Horrela, atzerritarraren barneratzeari buruzko erabakia pertsonaren inguruabar eta portaeran oinarritu beharko da, era horretan, kanporatzea ekiditeko benetako arriskua dagoenean soilik burutuko delarik atxiloketa. Kanporatzea ekiditeko arriskuaren adierazgarri dira, adibidez, ez izatea etxebizitza finkorik, erlazio egonkorrik, bizibiderik edo nortasun-agiririk. Aitzitik, kanporatze-agindua egon arren, atzerritarra aspalditik erroldaturik egoteak, lan-eskaintza sendoa, kontu-korrontea edo osasun-txartela izateak edo trebakuntza-ikastaroetan parte hartu izanak agerian jartzen dute atzerritarra finkaturik dagoela eta egoitza-baimena lortu ahal duela, eta horregatik ez dago ihes egiteko arriskurik ${ }^{80}$.

Giza Eskubideen Europako Auzitegiaren aurrean planteatutako kasuistika begiratuta, Auzitegiak adierazi du, adibidez, atzerritarrak jatorrizko Estatura itzultzeko asmorik ez duela baieztatzetik edo bere bikoteak leku horretara joateko hegaldi-plana zehazten duen jakinarazpena sinatzea ukatzetik ezin daitekeela ondorioztatu kanporatzea ekiditeko zantzuak daudenik, eta horrela egingo balitz, 5. artikuluak galdatzen duen interpretazio murriztailea gaindituko litzateke, batez ere, kontuan izanda atzerritarrak, Estatura heldu zenetik, jarritako betebehar guztiak bete dituela, adingabeko lau seme-alaba dituela eta bere emazteak gaixotasun psikiko bat duela ${ }^{81}$.

Jurisprudentzia horretan nabari denez, barneratzea ez da kasu guztietan erabaki behar den neurria. Bestalde, askatasunerako eskubidearen salbuespenak modu zorrotzean interpretatu behar direla aintzat hartuz, murriztapen hori askatasun-gabetuak gertatuko diren pertsonei bidalitako komunikazioen fidagarritasunera ere hedatzen da. Horrela, irizpide horren aurkakoa izango litzateke polizia-instalazioetara euren eskaerak osotzera, zuzentzera, eta abarrera joateko "gonbitea" egiten zaienean pertsona jakin batzuei, horren benetako arrazoia pertsona horiek kontrolpean edukitzea denean atzerritarrak kanporatzeko planifikatutako operazio baten eraginkortasuna errazteko ${ }^{82}$.

\footnotetext{
79 Tomé García (2015: 165-177).

80 Valentziako Probintzia Auzitegiko 2. Atalaren Autoa, 2008ko uztailaren 16koa.

81 Jusic u. Suitza, 2010eko abenduaren 2ko Epaia, 77-83. atalak.

82 Conka u. Belgika, 2002ko otsailaren 5eko Epaia, 42. atala.
} 
Kanporatze-agindua betearaziko dela bermatzea bilatzen duen barneratzearen konfigurazioak, hura bada azkenik prozedura zehatzailean jartzen den zehapena, berarekin dakar kanporatzea ezinezkoa baldin bada (atzerritarrak ez duelako nortasun-agiririk, jatorrizko Estatuak ez duelako atzerritarra bere lurraldean hartuko, eta abar) ezin izango dela atzerritarra barneratu; kautelazko neurri horren xedea kanporatzea benetan gauzatuko dela bermatzea da, beraz, kanporatzea ezinezkoa bada, ez litzateke barneratzerik egon beharko. Europar Batasuneko Justizia Auzitegia ere interpretazio horren aldekoa da epairen batean ikusi denez “... sólo una perspectiva real de que la expulsión puede llevarse a buen término (...) corresponde a una perspectiva razonable de expulsión, y que ésta no existe cuando parece poco probable que el interesado sea admitido en un tercer país (...)"83. Hori horrela izanda, instrukzio-epaileak atzerritarraren barneratzea erabakitzeko baloratu behar dituen inguruabar zehatzez gain, kanporatzea hirurogei eguneko epean betearazteko benetako perspektiba dagoen ala ez ere neurtu beharko du ${ }^{84}$.

Giza Eskubideen Europako Auzitegiak ere alderdi hori azpimarratu du; azken finean Hitzarmenak adierazten du kanporatze-prozedura batean murgildurik dauden pertsonak atxilotu ahal izango direla, hala badagokio ${ }^{85}$. Atxiloketa justifikaturik egongo da soil-soilik kanporatzea egingarria denean. Beraz, kanporatzeko ezintasunaz ohartu bezain laster, askatasun-gabetzea mantentzea Hitzarmenaren 5.1.f) artikuluaren aurkakoa da. Estrasburgoko Auzitegiaren esanetan, helburu horretarako kontuan izan behar da agintari eskudunek, beharrezko bidaia-agiriak lortu ahal izateko azaldu duten $\operatorname{ardura}^{86}$, berriz hartzeko akordioak sinatzea ${ }^{87}$, pertsona onartua izan dadin jatorriko Estatuarekin aurrera eraman diren negoziazioak ${ }^{88}$ eta abar. Estatu zehatz batera deportatzeko eragozpenak daudenean, baina beste leku batzuetara kanporatzea posible denean, askatasun-gabetzea justifikaturik egon daiteke, beti ere agintariek deportaziorako ahalegin aktiboak egiten badituzte ${ }^{89}$.

\section{ESKU-HARTZE JUDIZIALA BARNERATZEKO}

Barneratzeari buruzko erabakia, hala badagokio, prozedura zehatzailearen instrukzio-egileak eskatuta, atxiloketa egin den lekuko instrukzio-epaileak hartuko du, arra-

\footnotetext{
83 Europar Batasuneko Justizia Auzitegiaren 2009 ko azaroaren 30eko Epaia, C-357/09 PPU, Said Shamilovich Kadzoeu (Huchbarou).

84 Martínez Escamilla (2015: 44-45), Sánchez Tomás (2015: 72).

85 Giza Eskubideen Europako Hitzarmenaren 5.1.f) art.

86 Singh u. Txekiar Errepublika, 2005eko urtarrilaren 25eko Epaia, 64. eta 66-67. atalak.

87 Mikolenko u. Estonia, 2009ko urriaren 8ko Epaia, 57., 58. eta 64-68. atalak.

88 H.A. u. Grezia, 2016ko urtarrilaren 21eko Epaia, 49-54. atalak.

89 Al Husin u. Bosnia eta Herzegovina, 2019ko ekainaren 25eko Epaia, 104. atala.
} 
zoitutako auto bidez, interesdunari entzunaldia emanez kontraesan-printzipioa bete dadin $^{90}$, bai eta fiskaltzari ere ${ }^{91}$. Ondorengo baimen judiziala pertsonaren segurtasunerako eskubidearekin bateraezina izango litzateke ${ }^{92}$. Beste gauza bat da, behin epaileak barneratzea baimendu duenean, baimen hori deuseztatzea, adibidez, interesdunari ez zitzaiolako entzunaldirik eman ${ }^{93}$. Horren harira, azpimarratu behar da era horretako erabaki batek ez lukeela eraginik izango aurreko atxiloketaren legezkotasunaren gain, bereizi behar baitira nabarmenki baliogabeak diren atxiloketa-tituluak (adibidez, auzitegiek euren eskumenetik kanpo emandakoak) eta beste jurisdikzio batek deuseztatu arte baliozkoak eta eraginkorrak diren atxiloketa tituluak ${ }^{94}$.

Prozeduran parte hartzen duten organoen dualtasunari dagokionez, administrazio-organoa eta epailea, Konstituzio Auzitegiak zehaztu zuen askatasun-gabetzea hirurogeita hamabi ordu baino gehiagoz luzatzen denean barneratzea eskatuko duen organoa administrazio-agintari eskuduna bada ere, erabakia epaileak hartuko duela egokia iruditzen bazaio ${ }^{95}$. Epaileak askatasunez erabakiko du kasu zehatzaren inguruabarrak aztertu ondoren, ez kanporatzeko erabakiaren inguruabarrak, baizik eta atzerritarrak egoitzarik edo nortasun-agiririk ez izateagatik ez agertzeko arriskuarekin, kanporatzea zaildu edo ekiditeko bere portaerarekin, aurretiazko kondena edo administrazio-zehapenak egotearekin, osasun-egoerarekin eta bestelakoekin lotutakoak ${ }^{96}$. Kasu bakoitzaren inguruabarren azterketa egin beharrak multzoka hartutako barneratze-erabakiak eragozten ditu, atxilotutako pertsona bakoitzarekiko zehaztasunik gabekoak izateagatik defentsa-gabezia eragiten duen arrazoitze-gabezia baitakarte, ez baitira adierazten askatasun-gabezia justifikatzen duten arrazoiak ${ }^{97}$. Ezin daiteke, ezta ere, barneratzea justifikatzeko baliatu esku hartze judiziala galdatzen duen artikuluaren edukiaren transkripzioa egitea ${ }^{98}$, oro har kasuaren ustezko inguruabarrak aipatzea ${ }^{99}$, edo egindako atxiloketa erabat legearekin bat datorrela baieztatzea ${ }^{100}$. Baina edonola

90 Konstituzio Auzitegiaren 96/1995 Epaia, ekainaren 19koa, 3. OJ; Konstituzio Auzitegiaren 66/1996 Epaia, apirilaren 16koa, 3. OJ. Tomé García (2015: 177-181)

91 Atzerritarrei buruzko Lege Organikoaren 62. art. Sarrera ezezten denean bai eta itzularazte kasuetan ere, barneratzeko eskaera agintari eskudunek egingo dute. Behin atzerritarra barneratu denean, egonaldiaren kontrola zentroak kokaturik dauden lekuko epaileek eramango dute, edo hala badagokio, muga-postuetako errefusatu-guneetakoek. Martínez Escamilla (2015: 38-42).

92 Karimou u. Errusia, 2010eko uztailaren 29ko Epaia, 116. eta 117. atalak.

93 Richmond Yaw eta beste batzuk u. Italia, 2016ko urriaren 6ko Epaia, 76. atala.

94 Benham u. Erresuma Batua, 1996ko ekainaren 10eko Epaia, 42. atala.

95 Konstituzio Auzitegiaren 115/1987 Epaia, uztailaren 7koa, 1. OJ.

96 Konstituzio Auzitegiaren 144/1990 Epaia, irailaren 26koa, 4. OJ.

97 Konstituzio Auzitegiaren 144/1999 Epaia, irailaren 26koa, 5. OJ.

98 Konstituzio Auzitegiaren 182/1996 Epaia, azaroaren 12koa, 3. OJ

99 Konstituzio Auzitegiaren 169/2008 Epaia, abenduaren 15ekoa, 4. OJ. 
ere, askatasun-gabetzeari buruzko erabakia epailearena da, nahiz eta kanporatzeari eta horren betearazteri buruzkoak administrazio-izaera izan.

Hala ere, barneraturik dagoen pertsona epea amaitu aurretik askatzea, instrukzio-epaile eskudunak erabakitzeaz gain, bere ekimenez edo alderdiak zein fiskaltzak eskaturik, barneratze-zentroaren zuzendariak ere erabaki dezake. Horrela, behin askatasun-gabeturik dagoen pertsonaren barneratzea justifikatu zuten inguruabarrak desagertzen direnean, bai eta onartutako kanporatzea betearazteko ezintasuna sumatzen denean, bere kargura duen administrazio-agintariak askatuko du, horren berri emanez barneratzea baimendu zuen epaileari ${ }^{101}$.

\section{BARNERATZEAREN IRAUPENA}

Barneratzearen iraupena espedientearen helburuetarako ezinbestekoa dena izango da, eta inoiz ere ez hirurogei egun baino luzeagoa. Horri buruz, Konstituzio Auzitegiak adierazi zuen ${ }^{102}$, "ezinbesteko" hitza Legean iraupenari buruzkoa izan arren, ulertu behar dela askatasun-gabetzea bera ezinbestekoa izan behar dela, hau da, kanporatze-espedientea irekitzeak berez ez duela hura justifikatzen, kasuaren berezko inguruabarrek baizik. Kontuan izan behar da epaileak proportzionaltasun-printzipioaren arabera erabaki behar duela, betiere askatasun-gabetzearen aparteko izaeratik abiatuz, bai eta kautelazko neurria izatetik ${ }^{103}$. Bestela esanda, atzerritarraren barneratzea har daitezkeen kautelazko neurrien artetik bat baino ez da. Eta atzerritarrarentzat neurri murriztaileena da, beraz, horren alde egingo da beste neurriak nahikoak ez direnean soilik. Horregatik hitz egiten da barneratzearen apartekotasunaz, bai eta askatasuna errespetatzearen beharraz ere ${ }^{104}$, kautelazko edo prebentziozko arrazoiak direla-eta hura galtzea ezinbestekoa denean izan ezik ${ }^{105}$. Eremu horretan favor libertatis printzipioak bere hedadura osoarekin jokatzen du. Horregatik galdatzen zaio epaileari kasuaren inguruabar guztiak aztertzeko, horrela bakarrik ziurta baitaiteke barneratzea erabakiko dela dagokion helburua betetzeko beste kautelazko neurriak nahikoak ez direnean ${ }^{106}$.

Atzerritarra barneratu zenetik hirurogei egun igarotzen direnean, ez bada kanporatzea betearazi, hura askatu beharko da. Baina gehienezko iraupena hirurogei egune-

101 Atzerritarren Lege Organikoaren 62.3 art.

102 Konstituzio Auzitegiaren 115/1987 Epaia, uztailaren 7koa. 1. OJ.

103 Martínez Escamilla (2015: 42).

104 Madrilgo 41. Administrazioarekiko Auzien Epaitegiaren Autoa, 2007 ko otsailaren 3koa.

105 Konstituzio Auzitegiaren 115/1987 Epaia, uztailaren 7koa, 1. OJ; Konstituzio Auzitegiaren 144/1990 Epaia, irailaren 26koa, 4. OJ; Konstituzio Auzitegiaren 96/1995 Epaia, ekainaren 19koa, 2. OJ; Konstituzio Auzitegiaren 182/1996 Epaia, azaroaren 12koa, 3. OJ; Konstituzio

Auzitegiaren 169/2008 Epaia, abenduaren 15ekoa, 2. OJ. 
koa izateak ez du esan nahi epaileak barneratze bat baimentzen duen bakoitzean epe horretakoa izan behar denik. Epaileak iraupen gutxiagoko barneratzea ezar dezake, eta kasu horretan, kanporatzea edo askatzea epe laburragoan burutu beharko da. Askatasun-gabetzea hirurogei egunekoa baino laburragoa izan denean planteatzen dena da ea posible den barneratze berri bat erabakitzea gehienezko epea bete arte.

Barneratze-zentroen funtzionamendu eta barne-erregimenari buruzko Erregelamenduak ${ }^{107}$ adierazi zuen bere hasierako idazkeran, atzerritarra berriro barneratzea eska zitekeela, aurreko barneratzea justifikatu zuten arrazoi berberengatik, lehenengo barneratzea gehienezko iraupena baino laburragoa izan bazen, eta gehienezko iraupen horretara heldu arte ${ }^{108}$. Baliteke, idazkera horren jatorria Konstituzio Auzitegiak 115/1987 Epaian esandakoa izatea, horretan adierazi baitzuen gehienezko iraupen horren barruan epaileak askatasun-gabetzea baimendu dezakeela, eta iraupen laburragoa baimenduz gero, administrazio-agintariak barneratzearen luzapena eska dezakeela, legeak zehaztutako gehienezko denbora gainditu gabe ${ }^{109}$.

Haatik, Auzitegi Gorenak artikulu hori deuseztatu zuen, ulertu zuelako Atzerritartasunari buruzko Legearen kontrakoa zela, azken horrek adierazten baitu ezin dela barneratze berri bat erabaki espediente berean jasotako arrazoiak direla eta ${ }^{110}$. Auzitegiak berea egiten duen argudioa da Legeak, barneratzeari dagokionez, berme bikoitza ezartzen duela. Batetik, gehienezko iraupena eta, bestetik, espediente batean eta arrazoi berberengatik barneratze bakarra ${ }^{111}$.

Giza Eskubideen Europako Auzitegiak interpretazio bera egin du, bere ustez ez baita Hitzarmenarekin bateragarria kanporatze-agindu bat dela-eta pertsona bat atxilotzea eta askatasun-gabetzearen gehienezko iraupena igaro delako askatzen den une berean hura berriro atxilotzea. Kasu horretan, pertsona ez zen askatu, alde batetik, oraindik komisaldegian zegoelako eta, bestetik, ustezko askatzea mugatu zelako gauzatu ez zen askatze-akta sinatzera. Ondorengo atxiloketaren justifikazioa izan zen enbaxada batek egindako agiri faltsuak harrapatu zirela. Europako Auzitegiarentzat agiri horiek egoteak ez du berez justifikatzen aurrekoarengandik independentea den beste askatasun-gabetzea, beraz, bigarren atxiloketa lehenengoaren luzapena izango litzateke eta, legeak uzten duen gehienezko iraupena gainditzeagatik, Hitzarmenaren 5.1 artikuluaren kontrakoa ${ }^{112}$. Era berean, egoera irregularrean dagoen atzerritarra kanporatzeko asmoarekin atxilotzea ez dator bat Hitzarmenarekin, atxiloketa hori egiten

107 162/2014 Errege-Dekretua, martxoaren 14koa.

108 Barneratze-zentroen Erregelamenduaren 21.3 art.

109 Konstituzio Auzitegiaren 115/1987 Epaia, uztailaren 7koa, 1. OJ.

110 Atzerritarren Lege Organikoaren 62.2 art.

111 Auzitegi Gorenaren 2015eko otsailaren 10eko Epaia.

112 John u. Grezia, 2007ko maiatzaren 10eko Epaia, 33-36. atalak. 
bada behin hura estraditatzeko askatasun-gabetze epea gainditu denean ${ }^{113}$. Gauza bera esan daiteke, pertsona bat estraditatua izan dadin atxilotzen denean eta atxiloketaren gehienezko epea igarotzen denean berriro atxilotzen bada, oraingoan, kanporatzeko ${ }^{114}$.

Bueltatze-aginduaren ondorioz egindako barneratzearen inguruan, ez denez bere gehienezko epea ezartzen ${ }^{115}$, planteatu da hirurogei egun baino gehiagokoa izan daitekeela, nahiz eta bueltatzea atzerapenik gabe betearaz daitekeen neurria izan ${ }^{116}$. Hala ere, interpretazio hori eztabaidagarria da. Barneratze-zentroen arauketa bakarra kanporatzeei buruzkoa da, eta arauketa hori bueltatze eta itzularazteari ere zaie aplikagarri. Beraz, barneratuta dauden pertsonei aplikatuko zaien erregimena, barneratzera eraman duen arrazoia aintzat hartu gabe, atzerritartasunari buruzko araudian ezarritakoa bada, ez da ulergarria puntu zehatz horretan haien egoera larriagotzea.

\section{BARNERATZE-AUTOAREN AURKAKO ERREKURTSOA}

Barneratze-autoaren aurka apelazio-errekurtsoa jarri ahal da. Puntu honetan garrantzitsua da adieraztea, errekurtsoa ebatzi aurretik atzerritarraren aurkako kanporatze-agindua betearazteak edo bueltatzea zein itzularaztea gauzatzeak, ez duela prozesua objektu gabe uzten. Nahiz eta atzerritarra deportatu zenetik barneratzea amaitu den, auzitegi eskudunak autoak barneratzea justifikatzeko arrazoi nahikoak zituen aztertu behar du, pertsonaren askatasunerako oinarrizko eskubideari eragiten dion aparteko neurria da-eta. Horrela egingo ez balitz, apelazio-errekurtsoa ezagutu behar duen auzitegiak berak askatasunerako eta benetako babes judizialerako oinarrizko eskubideak urratuko lituzke ${ }^{117}$.

\section{HABEAS CORPUS PROZEDURAREN BEREZITASUNAK ATZERRITARTASUNARI BURUZKO LEGEDIAREKIN BAT EGINDAKO ATXILOKETETAN}

\section{ALDERDI OROKORRAK}

Habeas corpus baliabidea legez kontrakoak diren atxiloketa edo barneratze-egoerei aurre egiteko aurreikusirik dago, bere xedea askatasun-gabetze irregularra ahalbidetu

113 Azimou u. Errusia, 2013ko apirilaren 18ko Epaia, 161-165. atalak.

114 Eshonkulou v. Errusia, 2015ko urtarrilaren 15eko Epaia, 63-69. atalak.

115 Atzerritarren Lege Organikoaren 60.1 artikuluak dio: "bueltatzeko unea heldu arte".

116 Alonso Pérez (2002). Hala ere, egile horren ondorioa da, teknika juridikoko arrazoiak direla medio, arauetan adierazitako gehienezko epea dela aplikagarri. 
duten jarduerak berehala amaitzea baita, legez kontra atxilotu den pertsona epailearen aurrera eramanez ${ }^{118}$.

Konstituzio Auzitegiak jarraian adierazten den eran laburtu du habeas corpus-ari buruzko bere interpretazioa ${ }^{119}$ :

I. Habeas corpus prozedurak berme indartua ematen dio askatasunari, eta haren bidez epaile batek, ondoren, epaileen parte-hartzerik gabe erabakitako askatasun-gabetzeak legezkoak diren ala ez kontrolatuko du. Horretarako bere atxiloketa legez kontrakoa dela uste duen pertsona epailearen aurrera eramango da.

2. Prozesu arina eta erraza izan arren, legezkotasunari buruzko kontrola erabat eraginkorra izan behar da.

3. Habeas corpus-aren eskaeraren onargarritasuna eta askatasun-gabetzearen muinariari buruzko epaiketa bereizi behar dira. Atxiloketaren legezkotasunaren erabakia ezin daiteke onarpenari buruzko izapidean hartu, baizik eta muinari buruzko epaiketan, aurrez askatasun-gabeturik dagoen pertsona epailearen aurrera eraman eta entzunaldia eman behar zaiolarik, epaileak berak haren egoera pertsonala egiazta dezan. Ez balitz horrela egingo, askatasun pertsonalerako oinarrizko eskubidea urratuko litzateke. Edonola ere, epaileak erabakitzerakoan aintzat hartu behar dituenak ez dira kanporaketari buruzko inguruabarrak, hori administrazioarekiko auzien jurisdikzioari baitagokio ${ }^{\text {I20 }}$, baizik eta askatasun-gabetze zehatz hori legeren batean aurreikusirik dagoen ala ez. Hori horrela izanik, habeas corpus-a ez onartzea atxiloketaren luzapena atxilotuaren beraren portaeran oinarrituta, eta askatasun-gabetzea legearekin bat eta polizia-ahalaz baliatuz egin zela argudiatuta, atxilotua epailearen aurrera eraman gabe egindako muinari buruzko epaiketa da, Konstituzioaren I7.4 artikulua kontrakoa dena ${ }^{\mathrm{I2} I}$.

4. Aurrekoaren ondorioz, habeas corpus-aren eskaera ez onartzea, fiskaltzaren aurretiazko txostenarekin, forma aldeko betekizunak betetzen ez direnean erabakiko da.

5. Askatasun-gabetzea badago eta habeas corpus-aren eskaera aurkezteko forma aldeko betekizunak betetzen badira, askatasun-gabetzearen inguruko legezkotasunari buruzko edozein zalantzak eskaera onartu beharra dakar, kasuaren inguruabarrak aztertu beharko dira-eta. Horrela, ezin izango da eskaera ez onartu atxilotuaren askatasun-gabetzea legearen kontrakoa ez dela argudiatuz, erabaki hori habeas corpus-aren muinari buruzko prozeduraren objektua baita.

\footnotetext{
118 Konstituzio Auzitegiaren 98/1986 Epaia, uztailaren 10ekoa, 1. OJ.

119 Konstituzio Auzitegoarem 94/2003 Epaia, maiatzaren 19koa, 3. OJ; Konstituzio Auzitegiaren 23/2004 Epaia, otsailaren 23koa, 5. OJ; Konstituzio Auzitegiaren 122/2004 Epaia, uztailaren 12koa, 3. OJ; Konstituzio Auzitegiaren 303/2005 Epaia, azaroaren 24koa, 2. OJ.

120 Tomé García (2015: 172-173).

121 Konstituzio Auzitegiaren 179/2000 Epaia, ekainaren 26koa, 5. eta 6. OOJJ.
} 
6. Askatasun-gabetzeari dagokionez, bi betekizun betetzea galdatzen da. Batetik, benetako askatasun-gabetzea izatea eta, bestetik, ez izatea epaile batek erabakitakoa. Era horretako askatasun-gabetzeak dira poliziak egindako atxiloketak, atzerritartasunaren eremuan gauzatutakoak eta agintari militarrek diziplina-espedienteetan jarritako etxe barruko arrastatze-zehapena.

Giza Eskubideen Europako Auzitegiak ere gai horri buruz erabakitzeko aukera izan du, Hitzarmenak berak jasotzen baitu atxiloketa prebentibo eta barneratzearen bidez askatasun-gabeturik dagoen edonork epailearen aurrean errekurtsoa jartzeko eskubidea duela, azken horrek epe laburrean askatasun-gabetzearen legezkotasunaz, eta legez kontrakoa bada, askatzea erabaki dezan ${ }^{122}$. Beraz, eskubide hori ez dagokie soilik espetxe prebentiboan daudenei, baizik eta zalantzazkoa izan daitekeen askatasun-gabeziak ukiturik dagoen edonori ${ }^{123}$. Edonola ere, abiapuntua izanik atxiloturik dagoen pertsona orok hartutako neurriaren legezkotasuna epaile batek gainbegiratzeko eskubidea duela, administrazio-bidean eta epailearen erabakietan oinarritutako atxiloketak bereizten ditu. Lehenengoei dagokienez, Estatuek bermatu behar dute atxilotutako guztiek izango dutela auzitegien aurrean errekurtsoa jartzeko eskubidea. Bigarren kasuan, aldiz, Hitzarmenaren 5.4 artikuluak jasotzen duen gainbegiratzea epailearen erabakiak bere baitan hartzen duela ulertzen da (erantsitako kontrolaren doktrina) $)^{124}$. Edozein kasutan, atxiloketa legezkoa izan arren, ezin uler daiteke haren legezkotasunaren berrikuspena beti epailearen erabakian sarturik dagoela, erabakia hartzerakoan kontuan izan ez ziren inguruabar berriak agertu daitezke-eta ${ }^{125}$.

\section{HABEAS CORPUS-A ABIARAZTEKO AUTOA}

Oro har, epaile eskudunak zehaztutako betekizunak ematen diren ala ez aztertu beharko du, jarraian prozedura abiarazteko edo eskaera ezeztatzeko autoa emanik. Abiarazteko autoan epaileak askatasun-gabetua bere kontrolpean duen agintariari aginduko dio hura bere aurrera eramateko, kontraesan-printzipioaren garrantzia agerian gelditzen delarik. Muinari buruzko erabakia gehienez hogeita lau orduko epean hartuko da. Erabakiaren edukia honako bat izan daiteke: eskaera baiestea eta atxilotua askatzea, legearekin bat datorren askatasun-gabetzea jarraitzea, atxilotua berehala epailaren aurrera eraman beharra ${ }^{126}$.

\footnotetext{
122 Giza Eskubideen Europako Hitzarmenaren 5.4 art.

123 Stollenwerk u. Alemania, 2017ko irailaren 7ko Epaia, 35. atala.

124 Engel u. Herbehereak, 1976Ko ekainaren 8ko Epaia, 77. atala.

125 Sulaoja u. Estonia, 2005eko otsailaren 15eko Epaia, 74. atala; Suetoslau Dimitrou u. Bulgaria, 2008ko otsailaren 7ko Epaia, 69. atala.

126 6/1984 Lege Organikoa, maiatzaren 24koa, habeas corpus prozedura arautzekoa.
} 
Giza Eskubideen Europako Auzitegiak ere sarri azpimarratu du kontraesan-printzipioaren garrantzia atxiloketaren izaera arbitrarioa ekiditeko, hau da, epaileak askatasun gabeturik dagoen pertsonari bere defentsarako elementuak aurkezteko aukera ematearen beharra. Era horretan, ulertu izan du prozeduraren bermeak urratzen direla administrazio-izaera duen erabakia izanik ${ }^{127}$, epailearen berrikuspenik ez badago ${ }^{128}$; atxilotuari berari edo bere abokatuari ez bazaio uzten atxiloketari buruzko epaiketara joaten ${ }^{129}$; gaitasunak gutxiturik dituzten pertsonen barneratze luzeen kontrola egiaztatzeko jarraitutako habeas corpus prozedura nahikoa ez izatea ${ }^{130}$; barneratutako adingabe baten ${ }^{131}$ edo bere nortasun eta heldutasun mailaren arabera norbaiten arriskugarritasuna zehaztu behar denean ${ }^{132}$, bere abokatua prozeduran ez egotea; adingabe atzerritarrak abokatu batekin kontaktatu ezin izatea, eman zaion informazioa ulertzen ez duen hizkuntza batean ematea eta lagundutako adingabe gisa erregistratzea, nahiz eta legezko ordezkaririk ez izan ${ }^{133}$; atxilotutako pertsonak, delituak egin arren bere buruko gaixotasuna dela-eta ospitale psikiatriko batean dagoenak, atxiloketaren jarraipen, etendura edo amaierari buruzko ondorengo prozeduretan legezko laguntzarik ez izatea ${ }^{134}$, berak hori eskatu ez badu ere ${ }^{135}$; legezko laguntza independentea ${ }^{136}$ edo nahikoa ${ }^{137}$ ez bermatzea; atxilotuari edo bere abokatuari kasuaren espedienterako sarbidea ukatzea ${ }^{138}$, defentsa egokia bermatzea galarazten baita ${ }^{139}$; behin-behineko atxiloketaren legezkotasunari buruzko entzunaldia prestatzeko denbora nahikoa ez ematea, nahiz eta defentsak bista atzeratzea ez eskatu izana uler daitekeen eskubi-

127 De Wilde, Ooms eta Versyp u. Belgika, 1971ko ekainaren 18ko Epaia, 78-80. atalak.

128 Abdulazhon Isakou u. Errusia, 2010eko uztailaren 8ko Epaia, 129-131. atalak; Kolesnik u. Errusia, 2010 eko ekainaren 17ko Epaia, 88. eta 89. atalak.

129 Winterwerp u. Herbehereak, 1979ko urriaren 24ko Epaia, 61. atala; Al-Nashif u. Bulgaria, 2002ko ekainare 20ko Epaia, 92. atala; Frommelt u. Liechtenstein, 2004ko ekainaren 24ko Epaia, 36. atala; Kotsaridis u. Grezia, 2004ko irailaren 23ko Epaia, 32. atala; Farhad Aliyeu u. Azerbaijan, 2010eko azaroaren 9ko Epaia, 207. atala; Knebl u. Txekiar Errepublika, 2010eko urriaren 28ko Epaia, 87. atala; Khodorkouskiy u. Errusia, 2011ko azaroaren 28ko Epaia, 235. atala; Cernak u. Eslovakia, $2013 \mathrm{ko}$ abenduaren $17 \mathrm{ko}$ Epaia, 80-84. atalak.

130 X. u. Erresuma Batua, 1981eko azaroaren 5eko Epaia, 59. atala; H. L. u. Erresuma Batua, 2004 ko urriaren 5eko Epaia, 137. atala.

131 Bouamar u. Belgika, 1988ko otsailaren 29ko Epaia, 60. atala.

132 Waite u. Erresuma Batua, 2002ko abenduaren 10eko Epaia, 59. atala; Krowiak u. Polonia, 2007 ko urriaren 16ko Epaia, 51. atala.

133 Rahimi u. Grezia, 2011ko apirilaren 5eko Epaia, 120. atala.

134 Megyeri u. Alemania, 1992ko maiatzaren 12ko Epaia, 27. atala; Waite u. Erresuma Batua, 2002ko abenduaren 10eko Epaia, 59. atala.

135 Winterwerp u. Herbehereak, 1979ko urriaren 24ko Epaia, 66. atala; Megyeri u. Alemania, 1992ko maiatzaren 12ko Epaia, 23. atala.

136 Gorshkou u. Ukraina, 2005eko azaroaren 8ko Epaia, 44. atala; A. A. u. Grezia, 2010eko uztailaren 22ko Epaia, 77. atala.

137 Shulenkou u. Errusia, 2010eko ekainaren 17ko Epaia, 53. atala; Moghaddas u. Turkia, 2011ko otsailaren 15eko Epaia, 48. atala.

138 Nikolova u. Bulgaria, 1999ko martxoaren 25eko Epaia, 58. atala; Öcalan u. Turkia, 2003ko martxoaren 12 ko Epaia, 73. atala; Wesolowski u. Polonia, 2004ko ekainaren 22ko Epaia, 62. atala; Frommelt u. Liechtenstein, 2004ko ekainaren 24ko Epaia, 33. atala; Mooren u. Alemania, 2009ko uztailaren 9ko Epaia, 124. atala; Farhad Aliyeu u. Azerbaijan, 2010eko azaroaren 9ko Epaia, 203. atala. 
deari uko egite gisa ${ }^{140}$; arrazoirik gabe lekuko erabakigarri baten bertaratzea atzera botatzea $^{141}$; atxilotuaren osasun-egoera txarragatik eta atxiloketa-lekuan medikurik ez egoteagatik eskatutako habeas corpus-aren izapidetzea larregi atzeratzea ${ }^{142}$; epailearen kontrola txostenetan oinarriturik egotea soilik ${ }^{143}$; atxilotuaren azterketa psikiatrikoa atzeratzea langileen gabezian oinarritzea ${ }^{144}$; abokatuari ez uztea askatzearen aldeko argudioak azaltzen, horiek zehatzak, egokiak eta garrantzitsuak direnean ${ }^{145}$; atxiloketaren arrazoiei buruzko informaziorik ez ematea eta legezko laguntza ukatzea ere $^{146}$; abokatuari auzitegiaren saioetara joaten utzi arren, saio horiek kontraesan-entzunaldi izaera ez izateagatik, ahozko proposamenak aurkezteko aukerarik ez bermatzea, idatzizko proposamenak aurkezteko aukerak ez duenean bermatzen armen berdintasuna ${ }^{147}$; borondatezko deportazioa onartu duen pertsonen atxiloketaren prozedura arautzen duen legerik ez egotea ${ }^{148}$; berrikuspena epaile militarrek egitea, horien independentzia bermaturik ez badago ${ }^{149}$; atxiloketaren legezkotasunaren berrikuspenaren prozeduraren testuinguruan atxilotuari edo bere abokatuari fiskalaren iritzia ez helaraztea ${ }^{150}$ eta abar.

Aurreko atalean adierazitako alderdi guztiek agerian jartzen dute prozeduraren kontraesan-printzipioak duen garrantzia, haren bidez alderdien arteko beharrezko armen berdintasuna bermatzen baita ${ }^{151}$. Berdintasun horrek atxilotutako pertsona epailearen aurrean fiskalarekin aldi berean egotea galdatzen du, horrela azken horren ondorioak ihardetsi ahal izango dira-eta ${ }^{152}$, bereziki, erabakia hartu behar denean atxilotuaren nortasun eta egoera pertsonalaren arabera, bai eta auzitegiak atxiloketa luzatzeko asmoa duenean ordezkariari informazio egokia eman ahal izateko ere ${ }^{153}$.

\footnotetext{
140 Frommelt u. Liechtenstein, 2004 ko ekainaren 24ko Epaia, 33-34. atalak.

141 Beccieu u. Moldavia 2005eko urriaren 4ko Epaia, 74-75. atalak.

142 Sarban u. Moldavia 2005eko urriaren 4ko Epaia, 117. atala.

143 Kilicoglu u. Bulgaria 2005eko urriaren 20ko Epaia, 28. atala.

144 Fuchser v. Suitza 2006ko uztailaren 13ko Epaia, 43. atala.

145 Suershou u. Ukraina 2008ko azaroaren 27ko Epaia, 71. atala.

146 Abdolkhani eta Karimnia u. Turkia 2009 ko irailaren 22ko Epaia, 139-142. atalak; Farhad Aliyeu u. Azerbaijan 2010eko azaroaren 9 ko Epaia, 208. atala.

147 Farhad Aliyeu u. Azerbaijan 2010eko azaroaren 9ko Epaia, 208. atala; Khodorkouskiy u. Errusia 2011ko maiatzaren 31ko Epaia, 221. atala.

148 Nowak u. Ukraina 2011ko martxoaren 31ko Epaia, 70. atala.

149 Ali Osman Özmen u. Turkia 2016ko urriaren 5eko Epaia, 86-89. atalak; Kerman u. Turkia 2017ko azaroaren 22ko Epaia, 49-52. atalak.

150 Rusen Bayar u. Turkia 2019ko otsailaren 19ko Epaia, 69-74. atalak.
}

151 Sánchez-Reisse u. Suitza 1986ko urriaren 21eko Epaia, 51. atala.

152 Kampanis u. Grezia 1995eko uztailaren 13ko Epaia, 58. atala.

153 G. O. u. Errusia 2012ko urtarrilaren 18ko Epaia, 95. eta 96. atalak. 


\section{ATZERRITARREN BARNERATZEAN ESKU-HARTZE JUDIZIALA ETA HABEAS CORPUS-A EZ ONARTZEA}

Barneratzea, askatasun-gabetze era gisa, arlo askotatik oso kritikatutako neurria da atzerritarren askatasunerako eskubidearengan daukan eragin zuzen-zuzena dela-eta ${ }^{154}$. Gainera, 2009an burututako Atzerritarren Lege Organikoaren erreformak ${ }^{155}$ barneratze-zentroetan egonaldia berrogei egunetik hirurogei egunera luzatu zuen. Gogortze hori, nolabait, "bueltatze Zuzentaraua"156 deiturikoaren transposizioaren isla izan zen. Zuzentarauaren xede nagusia atzerritarren egoera irregularra amaitzea da, eta hori lortzeko zenbait neurri jasotzen du. Zeregin horretan, Zuzentarauak, aurreko epigrafeetan azaldutako antzerako eran, barneratzea bera ere jasotzen du, bai eta legez kontrako barneratzeei aurre egiteko bermeak ere. Horretaz gain, barneratzearen iraupena sei hilabete artekoa izan daitekeela adierazten du eta, inguruabar jakin batzuk gertatuz gero, beste hamabi hilabetez luza daitekeela ${ }^{157}$.

Azaldu denez, har daitezkeen kautelazko neurrien artean, barneratzeaz gain, pertsonen askatasunarentzat horren zorrotzak ez diren beste batzuk jasotzen ditu arauak, hots, agintari eskudunen aurrean aldian-aldian aurkeztea, nahitaez toki jakin batean bizitzea eta pasaportea edo naziotasuna egiaztatzeko agiria kentzea ${ }^{158}$. Beraz, ez dago oztoporik, agintari eskudunek atzerritarraren barneratzea eskatu arren, epaileak, egoki baderitzo, barneratzea ez den beste neurri alternatibo bat onartzeko ${ }^{159}$.

Barneratze-neurria, askatasun-gabetzailea izateagatik, habeas corpus-a eskatzeko kasuetako bat da, Konstituzioaren 17. artikuluan jasotzen diren eskubideen defentsarako baliabide bat ezartzeko prozedura gisa ${ }^{160}$. Prozedura horren bidez bilatzen da atzerritarraren askatasun-gabetze irregularra berehala amaitzea, bai eta pertsona hori lehen baino lehen epailearen aurrera eramatea ${ }^{161}$. Edonola ere, barneratzea epaile batek erabaki duenez, barneratzeko kautelazko neurriaren kontrol judizialaren erregimenetik eratorritako askatasun pertsonalerako bermeak, eraginkortasunaren ikuspuntu-

154 Rodríguez González (2003: 46 y 48), Teixeira Rodríguez (2005: 727-729), Gisbert Casasempere (2007), Moya (2008).

155 2/2009 Lege Organikoa, abenduaren 11koa, Atzerritarren Lege Organikoa erreformatzekoa.

156 2008/115/CE Zuzentaraua, Europako Parlamentuarena eta Kontseiluarena, 2008ko abenduaren 16koa, egoera irregularrean dauden hirugarren estatuetako nazionalen bueltatzerako kide diren estatuetan arau eta prozedura erkideak ezartzekoa.

157 2008/115/CE Zuzentaraua-ren 15. art.

158 Atzerritarren Lege Organikoaren 61.1 art.

159 Martínez Escamilla (2015: 43).

160 Konstituzio Auzitegiaren 21/1996 Epaia, otsailaren 12koa, 5. OJ; Konstituzio Auzitegiaren 66/1996 Epaia, apirilaren 16koa, 3. OJ; Konstituzio Auzitegiaren 86/1996 Epaia, maiatzaren 21ekoa, 10. OJ; Konstituzio Auzitegiaren 174/1999 Epaia, irailaren 27koa, 4. OJ; Konstituzio Auzitegiaren 179/2000 Epaia, ekainaren 26koa, 5. OJ; Konstituzio Auzitegiaren 303/2005 Epaia, azaroaren 24koa, 3. OJ. Martínez Pardo (2006: 53-66). 
tik, habeas corpus-aren bidetik lor daitezkeenen baliokideak dira ${ }^{162}$. Zentzu horretan, Konstituzio Auzitegiak adierazi du atzerritartasunaren eremuan habeas corpus prozedura eskatu ahal izango dela soilik kautelazko gobernu-atxiloketen kasuan (lehenengo hirurogeita hamabi orduetan) edo, atxiloketa-epea barneratzea baimendu duen epaileak adierazitakoa baino luzeagoa denean. Kasu horietatik kanpo, hau da, barneratzea epaileak baimendu eta horrek adierazitakora egokitzen denean, habeas corpus-a onartzea erredundantea izango litzateke. Baina habeas corpus-a ez onartzea zilegi izango da egiaztaturik badago aurrez epaileak entzunaldia eman ziola askatasun-gabeturik dagoen pertsonari eta horrek abokatu eta interpretea izan zituela, hau da, atxiloketaren egoerari buruzko epailearen benetako kontrola egon dela egiaztatzen denean. Giza Eskubideen Europako Auzitegiak "erantsitako kontrolaren doktrina” deitzen duenaren adierazgarri izango litzateke.

Edozein kasutan, habeas corpus-a ez onartzea, arrazoitua izan behar dena betetzen den kasu zehatza aipatuz ${ }^{163}$, Konstituzio Auzitegiaren aurrean babes-errekurtsoaren objektu izan daiteke, nahiz eta ezin izango den esan haren ezeztatzea konstituzio-kontrakoa denik askatasun-gabetzearen erabakian epaileak parte hartu duenean ${ }^{164}$. Konstituzio Auzitegiak babesa emango du aipatu diren inguruabarrak bete ez direnean, adibidez, ez bada egiaztatu epaileak entzunaldia eman ziola askatasun-gabeturik dagoen pertsonari nahiz eta, atzerritartasunari buruzko legediarekin bat, epaileak aurreikus dezakeen laster parte hartu beharko duela habeas corpus-aren eskatzailearen barneratzeari buruzko erabakia hartzeko. Horren arrazoia da habeas corpus-a pertsonaren askatasunaren bermerako beste baliabieetatik independentea dela, eta horren ondorioz, eskaera ez onartzeko aukera epaileak benetan atxilotuari entzunaldia eman dionean soilik gauzatu ahal izango dela ${ }^{165}$.

Nazioarteko babesa muga-postuetan eskatu duten pertsonen kasuan, atzerago adierazi den bezala, eskaera ebazten ez den bitartean leku horretan egoteak, hirurogeita hamabi orduak gaindituta, ez dakar kasu guztietan konstituzio-eskubideen kontrakoa den askatasun-gabetzea. Edonola ere, pertsona horiek ere, epaileen benetako babeserako eskubidearen tituludun gisa, habeas corpus prozedurarako sarbidea dute,

162 Konstituzio Auzitegiaren 303/2005 Epaia, azaroaren 24koa, 5. OJ; Konstituzio Auzitegiaren 169/2006 Epaia, ekainaren 5ekoa, 4. OJ; Konstituzio Auzitegiaren 19/2007 Epaia, otsailaren 12koa, 2. OJ; Konstituzio Auzitegiaren 20/2007 Epaia, otsailaren 12koa, 2. OJ; Konstituzio Auzitegiaren 169/2008 Epaia, abenduaren 15ekoa, 3. OJ.

163 Konstituzio Auzitegiaren 66/1996 Epaia, apirilaren 16koa, 5. OJ.

164 Konstituzio Auzitegiaren 303/2005 Epaia, azaroaren 24koa, 3. eta 5. OOJj; Konstituzio Auzitegiaren 315/2005, 316/2005, 317/2005, 319/2005, 321/2005 Epaiak, abenduaren 12koak, 2. O0Jj; Konstituzio Auzitegiaren 201/2006 eta 213/2006 Epaiak, uztailaren 3koak, OJ bakarrak; Konstituzio Auzitegiaren 172/2008 Epaia, abenduaren 18koa, 3. OJ; Konstituzio Auzitegiaren 173/2008 Epaia, abenduaren $22 \mathrm{koa}, 3$. eta 4. OOJJ. Pérez Sola (2008: 246-260).

165 Konstituzio Auzitegiaren 169/2006 Epaia, ekainaren 5ekoa, 4. OJ; Konstituzio Auzitegiaren 201/2006 eta 202/2006 Epaiak, uztailaren 3koak, 1. OOJJ; Konstituzio Auzitegiaren 273/2006 Epaia, irailaren 25ekoa, 2. OJ 2; Konstituzio Auzitegiaren 19/2007 Epaia, otsailaren 12koa, 2. OJ; Konstituzio Auzitegiaren 172/2008 Epaia, abenduaren 18koa, 3. OJ; Konstituzio Auzitegiaren 173/2008 Epaia, abenduaren 22koa, 4. OJ. 
kontuan izanik askatasun-gabetzea ez duela epaile batek erabaki. Aukera hori onargarria izango litzateke behin eskaera onartu ez edo administrazio-isiltasunaren bidetik onartu arren, eskatzailea oraindik muga-postuan dagoenean ${ }^{166}$.

\section{ONDORIOAK}

Askatasunerako oinarrizko eskubidea, giza duintasunarekin duen lotura dela-eta, pertsona guztiek duten eskubidea da, aintzat hartu gabe zein den horien nazionalitatea edo Estatuko lurraldean duten administrazio-egoera. Beraz, atzerritarrei ere dagokie eskubide hori, nahiz eta, inguruabarrei so eginez, legediak horien askatasun-gabetzea ekar dezaketen kasuak jasotzen dituen, nazionalitatea dutenei inoiz ere aplikatuko ez zaizkienak.

Zehazki, araudiak barneratze-neurria aurreikusten du, atzerritarra jatorrizko lekura bidaliko dela erabakitzen denean edo erabaki daitekeenean hartuko dena, lurraldean sartzeko legezkoak ez diren bideak erabili direlako edo bere administrazio-egoera irregularra delako. Askatasun-gabetzea kasu horietan bueltatzea, itzularaztea edo kanporatzea gauzatzea galaraziko lukeen ihes egiteko arriskuan oinarritzen da.

Barneratzea "bueltatze Zuzentarauan" deiturikoan zein atzerritartasunari buruzko araudian jasota egon arren, haren proportzionaltasuna da zalantzan dagoena. Kontuan izan behar da barneratzea erabakitzen denean administrazio arau-hauste hutsa egin duten pertsonen askatasunerako oinarrizko eskubidea mugatzen dela, ez delitu bat egin dutenena. Horregatik barneratzeko aukera erabat murriztu beharko litzateke eta benetan ihes egiteko arriskua dagoen kasuetara mugatu. Horrek prozesuan parte hartzen duten guztien konpromisua galdatzen du: ordezkaritza juridiko, fiskaltza eta epaileena. Lehenik eta behin, prozedura zehatzaileetan izapidetze arruntari lehentasuna emanez, horietan ez dago barneratzerik, eta lehenespenezko izapidetzea dagokion kasu zehatzetarako utziz. Bigarrenez, aurkeztutako kasu bakoitzeko inguruabarrak aztertzeko beharra azpimarratuz, kanporatzea gauzatzeko bideragarritasuna barne, horrela barneratzea arauek jasotzen dituzten beste neurriak eragindako pertsona etengabe aurkitzeko moduan egoteko nahikoak ez direnean soilik eskatu eta/edo erabakitzeko.

Subjektu horiek horrela jardungo dutela bermatuz gero, barneratzearen beharra, nahiz eta askatasunerako oinarrizko eskubidea murrizten duen neurria izan, errazago justifika daiteke. Edonola ere, puntu honetan ezinbestekoa da barneratze-guneen baldintza negargarriak, bai eta barneratutako pertsonek jasaten dituzten eskubideen murrizketak ere aipatzea, haien itxiera aldarrikatzera eraman dutenak. 
Barneratzeko erabakia betiere epaileak hartuko duenez habeas corpus prozedura bazterturik dago arau orokor gisa. Bai Konstituzio Auzitegiak, bai eta Giza Eskubideen Europako Auzitegiak ere ondorioztatu dute barneratze-erabakian epailearen kontrola eranstea eta habeas corpus prozeduraren objektua den askatasun-gabetzearen legezkotasunaren analisia baliokideak direla. Era horretan, egoera horietan zilegi izango litzateke aurkeztu diren eskaerak ez onartzea, baina ez barneratzea epailearen parte hartzerik gabe egin denean edo, epailearen barneratze-erabakia egon arren, barneratutako atzerritarra epailearen aurrean egon ez dela egiaztatzen bada.

Horren guztiaren ondorioz, atzerritarren askatasunerako eskubidearekin lotutako bermeei buruzko interpretazioak, bereziki barneratzearen legezkotasuna aztertuko duen esku-hartze judizialari dagokionez, ez darama berme horiek ezeztatzera, eremu horretan, ohiko atxiloketetan ez bezala, gertatzen den berezitasunari erantzuten baitio. $\uparrow$

\section{BIBLIOGRAFIA}

Agirreazkuenaga Zigorraga, I. (1994). Contexto de la Ley de Seguridad Ciudadana. Análisis jurídico de los controles de identidad: volutas legis e interpretación jurisprudencial del T.C. Revista Vasca de Administración Pública, 38, 13-56.

Alonso Pérez, F. (2002). La medida de internamiento en la nueva legislación de extranjería. La Ley: Revista jurídica española de doctrina, jurisprudencia y bibliografia, 7, 1753-1757.

Arrese Iriondo, M. N. (2015). Artículo 5. I. Lasagabaster Herrarte (Zuz.). Convenio Europeo de Derechos Humanos. Comentario sistemático, 3. edizioa, (113-202 orr.). Cizur Menor: Civitas Thomson Reuters.

Barbero González, I.; Blanco Fernández de Valderrena, C.; Arrese Iriondi, M. N. eta González Murúa, A. R. (2017). La defensa de los derechos fundamentales ante la detención, internamiento y expulsión de personas extranjeras. El caso de la Comunidad Autónoma Vasca. Valentzia: Tirant lo Blanch.

Barbero, I.; Blanco, C. eta Arrese, M. N. (2018). El internamiento de extranjeros: un análisis empírico de los procedimientos instruidos en la Comunidad Autónoma Vasca. Revista Vasca de Administración Pública, 110-I, 17-53. https://doi.org/10.47623/ ivap-ruap.110.2018.1.01

Bolaño Piñeiro, M. C. (prentsan). La acreditación y comprobación de la identidad y de la situación de regularidad de las personas extranjeras, en el marco de la Ley Orgánica 4/2015, de 30 de marzo, de Protección de la Seguridad Ciudadana. Derechos humanos, potestad sancionadora y organización administrativa en la seguridad ciudadana ikerkuntza-proiektua (PIBA 2019-48, Eusko Jaurlaritza). 
Charrier, J. L. (2005). Code de la Convention européenne des droits de l'homme. París: Litec.

De Meyer, J. (1999). Article 5.1. L. E. Pettiti, E. Decaux eta P. H. Imbert. La Convention Européenne des droits de l'homme, 2. edizioa, (189-201 orr.). Paris: Economica.

Donaire Villa, F. J. (2012). Detención e internamiento de extranjeros a efectos de expulsión. Régimen de los centros de internamiento de extranjeros. D. Boza Martínez, F. J. Donaire Villa eta D. Moya Malapeira (Koord.). La nueva regulación de la inmigración y la extranjería en España, (508-520 orr.). Valentzia: Tirant lo Blanch.

Fernández Arévalo, L. (2006). Extranjeros inscritos en el Sistema de Información de Schengen como no admisibles y eficacia en España de resoluciones de expulsión acordadas por otros Estados de la Unión Europea. Revista de Derecho Migratorio y Extranjería, 13, 31-55.

García Añón, J.; Bradford, B.; García Sáez, J. A.; Gascón Cuenca, A. eta Llorente Ferreres, A. (2013). Identificación policial por perfil étnico en España. Valentzia: Tirant lo Blanch.

Gisbert Casasempere, R. (2007). Las medidas cautelares de detención e internamiento en el procedimiento de expulsión de extranjeros. Actualidad administrativa, 2, 132-140.

Guillén Pérez, V. eta Prieto González, J. (2017). Tratamiento jurídico de un binomio cohesionado en la nueva Ley Orgánica de Protección de Seguridad Ciudadana; identificación y documentación. Revista de Derecho UNED, 21, 325-352.

https://doi.org/10.5944/rduned.21.2017.21169

Lasagabaster Herrarte, I. (prentsan). La identificación de personas por la policía: su regulación en la Ley de Seguridad Ciudadana. Derechos humanos, potestad sancionadora y organización administrativa en la seguridad ciudadana ikerkuntza-proiektua (PIBA 2019-48, Eusko Jaurlaritza).
Martínez Escamilla, M. (2015). Detención, internamiento y expulsión de ciudadanos extranjeros en situación irregular. Las funciones del juez de instrucción. M. Martínez Escamilla (Koord.). Detención, internamiento y expulsión administrativa de personas extranjeras, (29-53 orr.). Madril: Proyecto I+D+i lusmigrante (luspuniendi e inmigración irregular).

Martínez Pardo, V. J. (2006). Las privaciones de libertad de los extranjeros y el derecho de Habeas corpus. Revista Jurídica de la Comunidad Valenciana, 18, 49-75.

Moya Malapeira, D. (2002). La devolución de extranjeros en el ordenamiento jurídico español. Revista Vasca de Administración Pública, 62, 189262.

Moya Malapeira, D. (2008). La nueva Directiva de retorno y la armonización comunitaria de las medidas de alejamiento de extranjeros. Revista de Derecho Constitucional Europeo, 10, 101-164.

Nowak, M. (2005). U.N. Covenant on Civil and Political Rights. CCPR Commentary, 2. edizioa. Estrasburgo: Arlington.

Pérez Sola, N. (2008). Las limitaciones al derecho a la libertad en el ámbito de la extranjería y la operatividad del procedimiento del habeas corpus. RDUNED. Revista de Derecho UNED, 3, 233-260.

https://doi.org/10.5944/rduned.3.2008.10952

Requejo Rodríguez, P. (2006). El internamiento de extranjeros. Valentzia: Tirant lo Blanch.

Rodríguez González, M. P. (2003). Expulsión versus devolución en la vigente Ley sobre Derechos y Libertades de los Extranjeros en España y su integración social. Justicia administrativa: Revista de Derecho Administrativo, 21, 21-52.

Sánchez Tomás, J. M. (2015). Detención, internamiento y expulsión de ciudadanos extranjeros en situación irregular: marco comunitario e interna- 
cional. M. Martínez Escamilla (Koord.). Detención, internamiento y expulsión administrativa de personas extranjeras, (55-80 orr.). Madril: Proyecto I+D+i lusmigrante (luspuniendi e inmigración irregular).

Teixeira Rodríguez, X. (2005). Derechos de los extranjeros detenidos o internados en los procedimientos administrativos de retorno, expulsión y devolución. Anuario de la Facultad de Derecho de Ourense, 1, 727-750.

Tomé García, J. A. (2014). Internamiento preventivo de extranjeros conforme al nuevo Reglamente de los CIE. Madril: Colex.
Tomé García, J. A. (2015). La autorización del internamiento: principios rectores. M. Martínez Escamilla (Koord.). Detención, internamiento y expulsión administrativa de personas extranjeras, (165-181 orr.). Madril: Proyecto I+D+i lusmigrante (luspuniendi e inmigración irregular).

Velasco Caballero, F. (2007). Inmigración y policía administrativa de seguridad. Revista Catalana de Seguretat Pública, 17, 227-260. Hemendik eskuratua https://raco.cat/index.php/RCSP/article/ view/130223 